\title{
The Mosaic Floors of the House of Kyrios Leontis in Nysa Scythopolis (Beth Shean)
}

\section{Nysa Scythopolis 'teki (Beth Shean) Kyrios Leontis Evi 'nin Mozaik Zeminleri}

Lihi HABAS*

(Received 08 April 2021, accepted after revision 11 August 2021)

\begin{abstract}
The House of Kyrios Leontis in Nysa Scythopolis (Beth-Shean) was partially excavated by two expeditions and at different times, and the mosaic floors have been published only in preliminary publications. Two halls were discovered in the complex. The first hall is decorated with a mosaic pavement of three panels: the Homeric story of Odysseus and the Sirens; beribboned parrots surrounding a dedication inscription; the Nile god, Nilometer, the city of Alexandria, and a Nilotic landscape. The second hall served as a prayer room or a small synagogue. A pair of animals decorated the two entrances, and the hall itself is decorated with populated vine scrolls with animals. Jewish ritual objects appear in the central medallion: the seven-branched candlestick, citron, censer, and ram's horn. The mosaic floors are inlaid with dedication inscriptions in Hebrew, Aramaic and Greek, with the names of the donors and prayers for the holy congregation.

The iconography, incorporating mythological subjects, the god of the Nile and Nilotic landscape, Jewish ritual objects, common animal chase scenes, and the use of the three languages that were customary in Byzantine Palestine, expresses the character of the city of Nysa Scythopolis as a cultural city inhabited by a mixed, welleducated population.
\end{abstract}

Keywords: Nysa Scythopolis, Odysseus and the Sirens, Nilotic landscape, Synagogue, Seven-branched candlestick.

\section{$\ddot{\mathrm{O} z}$}

Nysa Scythopolis'teki (Beth-Shean) Kyrios Leontis Evi, iki seferde ve farklı zamanlarda kısmen kazllmış ve mozaik zeminlerden sadece ilk yayınlarda bahsedilmiştir. Yapı kompleksinde iki salon keşfedilmiştir. İlk salon üç panelden oluşan bir mozaik döşeme ile dekore edilmiştir: Odysseus ve Sirenler'in Homeros hikâyesi; bir ithaf yazıtını çevreleyen şeritli papağanlar; Nil tanrısı, Nilometer, İskenderiye (Alexandria) şehri ve Nilotik bir manzara. İkinci salon bir dua odası veya küçük bir sinagog olarak hizmet veriyordu. İki girişi bir çift hayvan süslemektedir ve salonun kendisi hayvanlarla dolu asma dallarlyla süslenmiştir. Yahudi ritüel nesneleri merkezi madalyonda görünür: Yedi kollu şamdan, ağaç kavunu, buhurdan ve koç boynuzu. Mozaik zeminler, adayan kişilerin isimleri ve kutsal cemaat için dualar ile İbranice, Aramice ve Yunanca ithaf yazttlarıly işlenmiştir.

Mitolojik konuları, Nil tanrisı ve Nilotik manzarayl, Yahudi ritüel nesnelerini, ortak hayvan kovalamaca sahnelerini ve Bizans Filistini'nde geleneksel olan üç dilin kullanımını içeren bu ikonografi, Nysa Scythopolis şehrinin karakterini karma ve iyi eğitimli bir nüfusun yaşadığı kültürel bir şehir olarak yansıtmaktadır.

Anahtar Kelimeler: Nysa Scythopolis, Odysseus ve Sirenler, Nilotik manzara, Sinagog, Yedi kollu şamdan.

\footnotetext{
* Lihi Habas, Institute of Archaeology, The Hebrew University of Jerusalem, Mt. Scopus, Jerusalem 91905, Israel. 0544-7066. E-mail: habaslihi@gmail.com 


\section{Introduction}

The House of Kyrios Leontis in Nysa Scythopolis (Beth Shean) was partially excavated by two expeditions at different times, on behalf of the Department of Antiquities and Museums. The site was first excavated by N. Zori in 1964, and in 1970-1972, another excavation was conducted by D. Bahat and A. Druks. The original plan of the complex is still unclear, but the excavations revealed that the complex included a system of rooms surrounding a courtyard (Fig. 1). This house was part of a wealthy quarter of the city ${ }^{1}$.

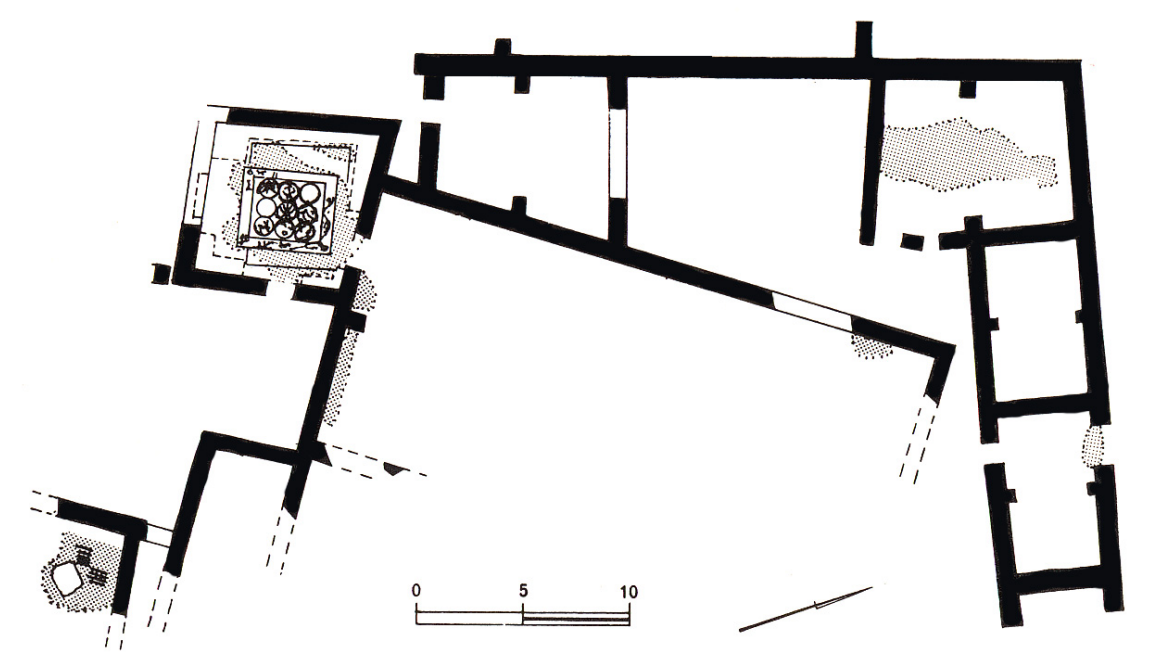

\section{Hall 3}

Zori's excavation uncovered part of the complex (Level V - dated to the middle of the fifth century AD). This consists of a courtyard surrounded by rooms, three of which have been excavated, and within them Hall $3(8.50-9.95 \times 7.10-7.70$ $\mathrm{m})$, which is paved with a mosaic floor ${ }^{2}$. The hall is decorated with a mosaic pavement of three panels (Fig. 2), surrounded by an edge adorned with small diamonds, and a unifying frame of simple shaded bands of guilloche on a black ground, and white dots. One band is made of black, white and red rows, the other of red, white and black rows (Avi-Yonah 1933: 138, Type B2; Ovadiah Ovadiah 1987: 233, Type B2; Décor I: 121 pl. 71c)33.

The upper panel (Fig. 3) depicts the Homeric story of Odysseus and the Sirens (Hom. Od. XII), and especially the verses: “... and they bound me in the ship hand and foot, upright in the step of the mast and made the ropes fast at the ends of the mast itself..." (Hom. Od. XII, 178-179) ${ }^{4}$. Odysseus is tied to the mast of the ship sailing in stormy waters. He is standing, his body shown schematically with grey contours, and he is wearing a kind of net skirt. Black contours shape his wavy brown hair, the arched eyebrows are black, the upper eyelids and the pupils are grey, and he is looking sideways and down towards the figure of the Nereid. The boat riding the waves has a rounded bow and a paddle.

1 My grateful thanks for their cooperation to the excavator Dan Bahat and Ayelet Dayan, editor of Hadashot Arkheologiyot, Israel Antiquities Authority (IAA). Photographs Dudi Mevorah, Israel Museum and Lihi Habas.

2 The mosaic was first published by Zori $(1966 ; 1967 ; 1973)$, and there is a short description in Ovadiah - Ovadiah (1987: 34-36). The panels are now displayed in the Israel Museum, Jerusalem. My deepest gratitude to Nelly Beyman, visual archives, IAA, and Dudi Mevorah, Israel Museum, for their help and cooperation

3 Definitions of the patterns from: Avi-Yonah 1933; Décor I; Ovadiah - Ovadiah 1987.

4 Homer, The Odyssey with an English translation by A. T. Murray, London, 1999, 160-200.
Figure 1

Plan of the house of Kyrios Leontis complex (after Bahat 1981: fig. on p. 83).

Figure 2

The mosaic floor of room 3 (after Zori 1966: fig. 3).

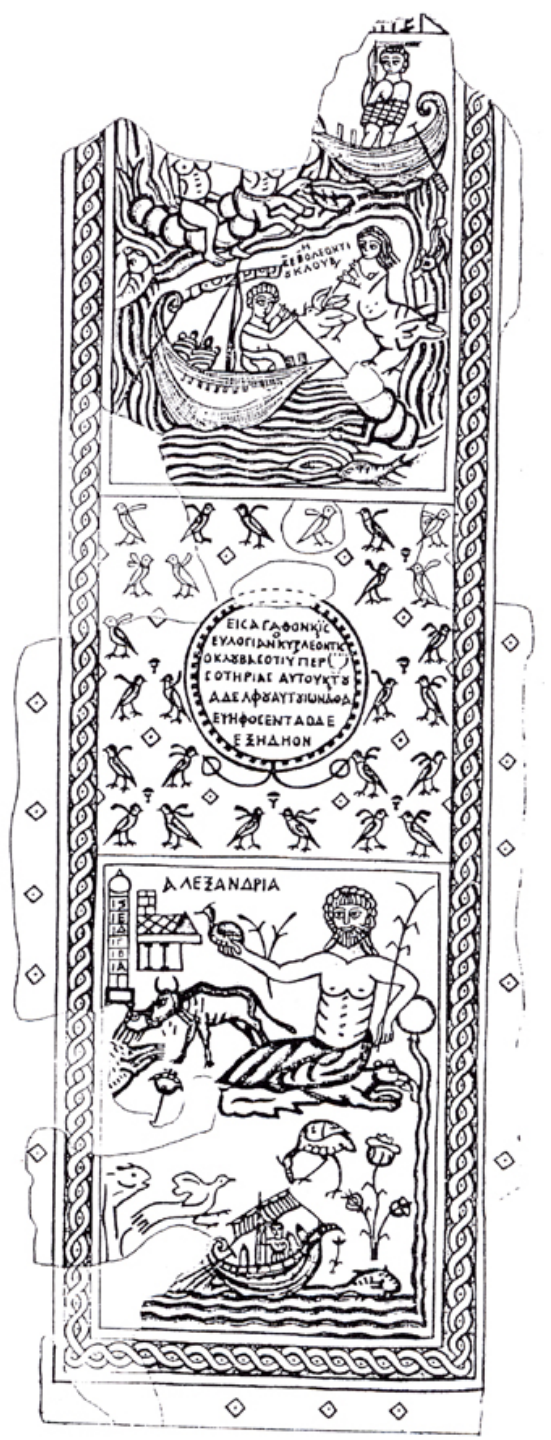


Figure 3

Room 3: Upper panel - Odysseus and the Sirens (Courtesy of D. Mevorah, Israel Museum, Jerusalem).

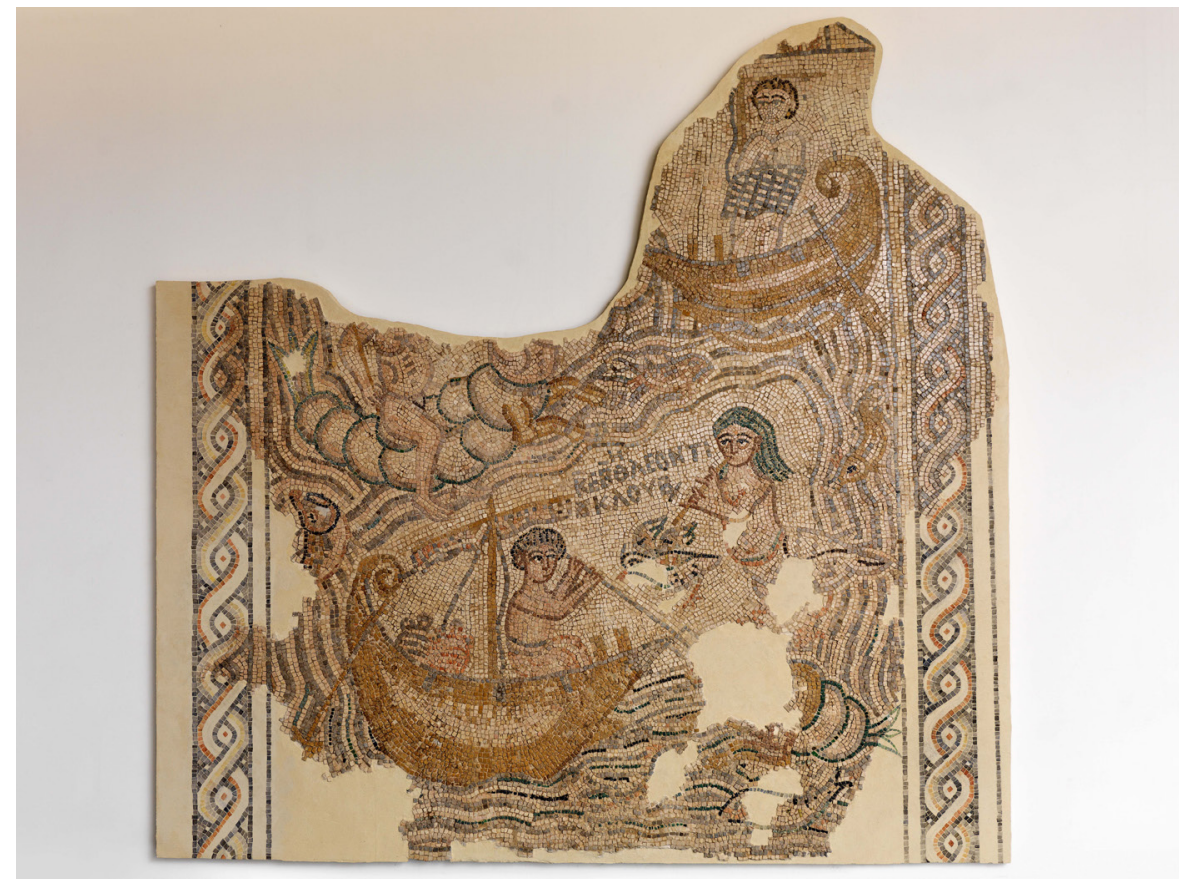

Below is a naked Nereid riding on a sea centaur (Ichthyocentaur), both of their heads are missing. Light brown outlines shape the details of the Nereid's body, depicted in a $3 / 4$ position - her hips and legs in profile and her upper torso frontal. Black and grey contours form a kind of vertebra that shapes the body of the monster. Brown contours outline the horse-like front legs, and grey outlines the fish tail that completes its body.

Another ship is sailing below, whose prow curves upwards, with a folded sail hanging from the mast by two cords. A young man, identified by Talgam as Odysseus fighting Scylla (2014: 376-377), is seated in the ship fighting a seamonster with an oar or other weapon, and behind it two pithoi are depicted. In front of the young man is a Siren, her upper body is human and naked, and the lower part has a bird's legs. She has a long hair that falls onto her shoulders, and she is playing a flute. Light brown contours depict the bodies of the Siren and the youth, grey-black stripes form her hair, and short black, grey, and white stripes shape the young man's curls. Both have black eyebrows, upper eyelids, and pupils, their lower eyelids are brown, and their gaze is turned upwards. Waves in black, white and grey stripes connect and unite all the details of the composition.

Depicted between Odysseus and the Siren are a bird in flight, fish in the sea,

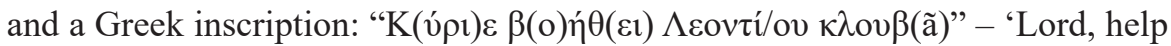
Leontis Kloubas' (Zori 1966: 132-133 pl. 11; 1973: 234 pl. 47:1; Roth-Gerson 1987: 34-35 fig. 12 no. 6). The formula 'Kúpı $\beta$ oń $\theta \varepsilon \imath$ ' is common in Jewish and Christian inscriptions, as found in the marble slab in the synagogue at Caesarea (Sukenik 1951: 29-30 pl. XV); and in the mosaic floors of churches, such as the chapel of Khirbat al-Kursi (Piccirillo - 'Amr 1988: 365-367 figs. 12-13; Piccirillo 1993a: 265 fig. 477), the church at Suf (Piccirillo 1993a: 315 fig. 650), the Lower Church of al-Quwaysmah (Piccirillo 1993a: 266), and the Church of St. Mary at Rihab (Piccirillo 1980a: 340-341 fig. 18 foto 42; 1980b: 154 pl. XCVIII: 2; 1993a: 311 fig. 625). The same formula appears in Aramaic inscriptions in Ma'on, Eshtamo'a, Horvat Susiya, El-Hammeh, and Na'aran synagogues (Roussin 1981: note 2 and references therein). Above the head of Odysseus and outside the panel, the end of a Greek inscription '...AMP' has been preserved. 


\section{Mythological Depictions in Secular Mosaic Floors in the Holy Land}

Mythological depictions in Byzantine secular mosaic floors have been discovered in the Holy Land. In Madaba, there are a few mythological scenes such as the tragedy of Phaedra and Hippolytus and the myth of Aphrodite and Adonis in the Hippolytus Hall, Banche and a satyr in Bacchic procession, Achilles, Patroclus, Eubreiseis and a Bacchic procession with a satyr playing a flute, and Heracles strangling the Nemean lion (Piccirillo 1993a: 66, 76-77, 80 figs. 3, 6, 32-33, 40, $43-44,48,80)$; and there is a fragmentary mythological scene in a villa at Gerasa with a Bacchic procession, Pan, Dionysus, a bacchante, and Aphrodite (Z'ubi et al. 1994: 540-546 fig. 2 photos 1-2). At Sheikh Zuweid the first panel depicts the tragedy of Phaedra and Hippolytus, with Eros, the nurse and the hunters. The second panel is divided into two registers, the top depicting Dionysus' triumph and the thiasus, which includes Dionysus, Eros, centaurs, a panther, a silenus, a satyr and a maenad. In the lower register is the drunken Heracles resting on the shoulder of a satyr with a panther, Pan, a satyr and a bacchante (Ovadiah - Ovadiah 1987: 51-53 pl. XL, no. 69; Ovadiah et al. 1991: 122-126 figs. on p. 123-125; Ovadiah 1997: pl. 37 figs. 1-2); Dionysus' triumph also appears in the Erez mosaic, with a man holding two tigers (Rahmani 1973: 263-264 pl. 56:1; 1975: 21-42 pls. 3-4); a centaur and dancing Amazons are depicted in Sepphoris (Weiss - Talgam 2002: 73-74, 77-80 figs. 12, 15-17); Pan and Orpheus in Jerusalem (Vincent 1901: 436-448 figs.; Bagatti 1952: 145-160 fig. 2); and Helios in his chariot in Hammath Tiberias, Sepphoris, Beth Alpha and $\mathrm{Na}$ 'aran (Aïn-Douq) synagogues (Vincent 1921: 442-443; Sukenik 1932: 35 pls. 1b, X; 1949: 9-11 pls. I-II; Dothan 1983: 39-40 pl. 29:1; Weiss 2005: 104-110 figs. 46-48).

The middle panel (Fig. 4) depicts beribboned parrots, with a ribbon tied to the neck and waving in the wind, facing each other, creating an array of diamonds, and within them small diamonds and buds. Dark green contours shape the head and wings, the body is in green stones, a row of grey stones marks the area under the wing, the beak, ribbons, and legs are light brown/orange, and the pupils are black on a white background.

In the centre is a Greek dedication inscription within a medallion, $100 \mathrm{~cm}$ in diameter. The medallion is made of an outer row of black stones, while the

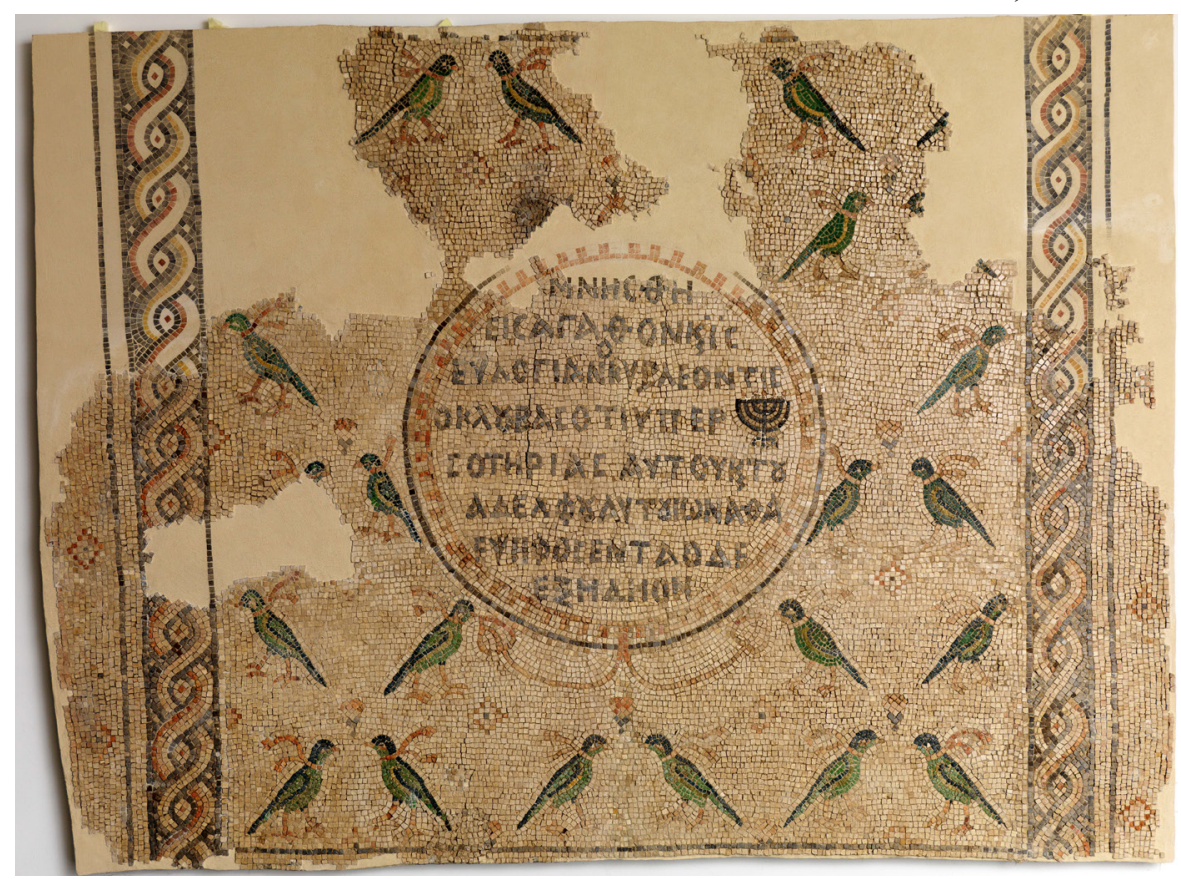

Figure 4

Room 3 - Greek dedication inscription surrounded by beribboned parrots (Courtesy of D. Mevorah, Israel Museum, Jerusalem). 
interior is a dentillated circle in light brown/orange. From the centre of the lower part two branches extend, ending with heart-shaped leaves. The inscription reads:

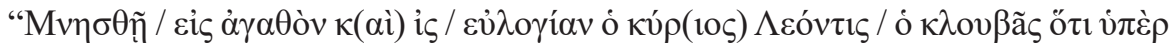

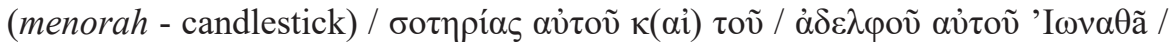

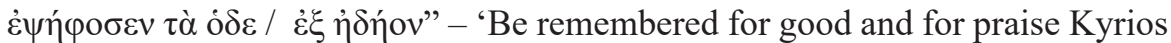
Leontis Kloubas because he paved this with mosaic at his own (expense) for his own salvation and that of his brother Jonathan' (Zori 1966: 130, 132-134 pl. 13:B-C; Lifshitz 1967: no. 77b; Zori 1973: 236 pl. 47:2-3; Ovadiah - Ovadiah 1987: 35 pl. XXXI:1-2, no. 31; Roth-Gerson 1987: 37-38 fig. 14). As noted, on the right side of the fourth line of the inscription is a candlestick. Zori identified five branches, but during the reconstruction of the mosaic made at the Israel Museum, it turned out that the candlestick had seven branches, of which only

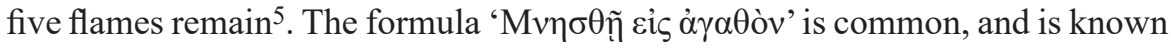
in mosaic floors in Hebrew, Aramaic and Greek in synagogues such as Beth Alpha, Hammath Tiberias, and Jericho, and on the marble chancel screen from Ashdod (Foerster 1981: 18-28; Roth-Gerson 1987: 19, 29, 69 figs. 1-2, 9, 29).

The motif of beribboned parrots, a ribbon tied to the neck and waving in the wind, originates in Persian and Sassanian art, where the waving ribbon -fativesymbolises the Persian/Sassanian dynastic power and royal glory. It is unclear whether the Persian symbol was transformed in Roman and Byzantine mosaic floors into a merely decorative element - an exotic appearance, or whether it maintained its symbolic value and meaning (Levi 1947: I: 358, 479; Kondoleon 2000: 137). Beribboned parrots, facing each other with the ribbons around their necks waving in the wind, appear in one of the rooms of Imhof Monastery, nearby in Nysa Scythopolis (Habas 2021 - forthcoming). In Madaba in Transjordan, the same parrots are found among other motifs in a diamond net made of rosebuds in the Upper Baptistery Chapel in the Cathedral complex (Piccirillo 1981: 312313 fotos 41, 43-44; 1989: fig. on p. 31; 1993a: 118 figs. 104, 116, 119), in the Church of Sunna' (Piccirillo 1993b: 286-288 fig. 4 fotos 16, 21), and in a scuta net in the Chapel of the Martyr Theodore (AD 562) in the Cathedral complex (Qandil 1969: 64 pl. 33:a; Saller 1969: 149-150 figs. 1, 13, 15; Piccirillo 1981: 304 fotos 11, 29; 1993a: 117 fig. 97). Sometimes it appears as an individual motif in a frame, as in the church at Horvat Berachot (Tsafrir - Hirschfeld 1979: 305-307 fig. F pls. 15-17, 19), in the church at Umm-Jerar (Drake 1918: 122124 fig.; Dalton 1919: 4 fig. on p. 7), and in the Church of the Lions at Umm al-Rasas (Piccirillo 1992: 213-214 fotos 31, 37 pianta I; 1993a: 236 figs. 338, $342-343,376)$. A composition of parrots facing each other with collars on their necks appears in the nave of the Church of the Apostles (AD 578) at Madaba (Lux 1968: 113, 119 taff. 14: a-b, 20:a-d, 21:a-d, 22:a-d, 30:a; Piccirillo 1989: 98 figs. on pp. 97-98, 102; 1993a: figs. 80-81, 95). All the parallels from Israel and Transjordan are dated to the fifth and sixth centuries AD.

The third panel (Fig. 5) depicts a panoramic Nilotic landscape. In the upper part the Nile god is sitting on a crocodile (Zori 1966: 131) or hippopotamus (Roussin 1981: 7; Balty 1984: 828), and resting on a globular jug from which water flows, as is customary in the depictions of river gods. The image of the god is large and prominent, his upper body is unclothed and his lower body is wrapped in a folded cloak. In his left arm he holds a plant, and in his right hand a fowl, and he points in the direction of a pillared building, with a pediment roof covered with tiles and a tower, above which is written A $\Lambda$ E $\Xi A N \triangle P I A$ - Alexandria. On the left side a Nilometer is depicted, standing on a rectangular base, with a

5 My thanks to Dudi Mevorah, Israel Museum, for bringing this to my attention. 


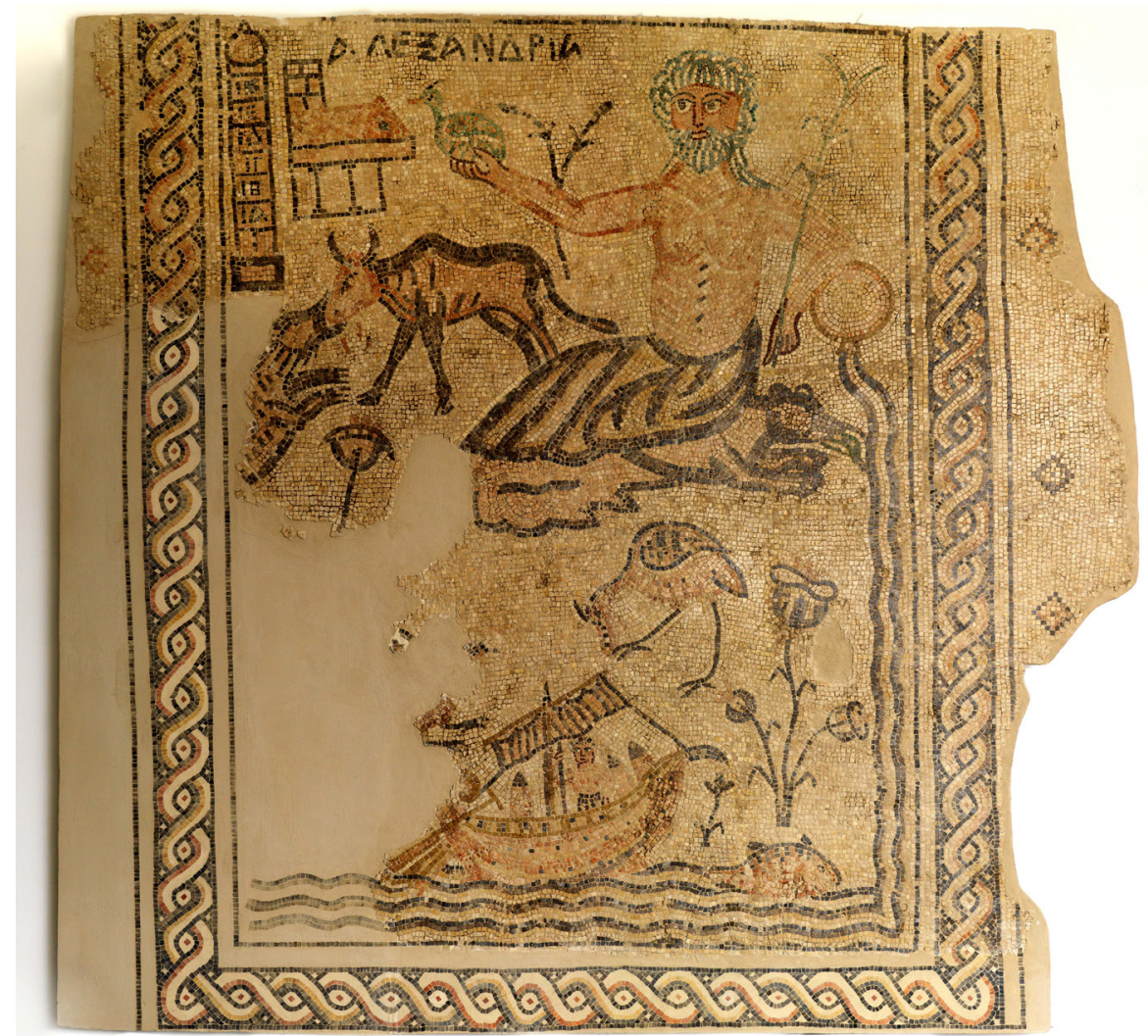

round upper end marked 11-16 (IA IB IГ I $\Delta$ IE IZ) for measuring the water level during the flood season. Between the god and the Nilometer is a combat scene between a leopard and a bleeding bullock. The lower part of the composition depicts the Nilotic landscape - the Nile River, on which a boat sails, its sail tied to the yardarm, spread out and fixed to the prow by ropes, with a wide rudder, and prominent, rounded prow. A young man is standing in a boat near the mast and holding a rope, and there is a cargo of three wine jugs covered with pointed lids. Above is a stork, bending down, and a flying bird, and on the right there are papyrus plants and big fish swimming in the river (Zori 1966: 131-133 pl. 12; 1973: 233, $236 \mathrm{pl}$. 48). All the elements that make up the composition are to be viewed from a single orientation, and the large size of the figures is also characteristic.

Brown/orange contour lines shape the upper body, and dark brown lines outline the palms and fingers of the Nile god, while broad black and white stripes indicate the folds of the robe. Short white and grey/green stripes form his curly hair, falling down to his shoulders, and his short beard. Dark brown lines form the arched eyebrows, elongated nose and lips. His eyes are large, with black pupils on a white background. His body is frontal, but his gaze is turned to the side. The water jug is designed in concentric circles in dark brown, orange and white colours. The details of the city of Alexandria and the Nilometer are designed in black lines, the tiles are orange. Black and grey contours form the body of the bullock (back, legs, hooves, tail and horns) and the body is a uniform light brown/ pink colour. Black and grey contours shape the body of the leopard, including the spots, legs and claws. The boat has a dark brown mast, the folds of the sail are designed in black and brown stripes, the rounded sides are brown, and the bow is black, while the body of the boat is designed in rows of rounded stones in black, brown/orange, beige and light brown, with scattered black stones. The young boy is depicted schematically from the front but his gaze is turned to the side, his upper body is naked and he is wearing a kind of black skirt. His short
Figure 5

Room 3 - Nilotic landscape (Courtesy of D. Mevorah, Israel Museum, Jerusalem). 
hair is black. The wine jars are brown, with black lids. The waves of the river are shaped in rows of white, black and light brown stones. Black contours shape the stork's body (back, wing, tail and legs) and its body is light, in white, light brown and white. Black/grey outlines shape the lotus flowers (stem, leaves and calyx) and orange and pink flowers grow from the calyxes.

\section{The Nilotic Landscape in the Mosaic Floors in the Holy Land}

The Nilotic landscape is depicted in the mosaics of Israel and Jordan in a secular context in public buildings and private homes, and in a religious context in churches and chapels. As in the House of Kyrios Leontis, it may be depicted in a large panel that includes most of the components of the composition (the Nile, the city of Alexandria, the Nilometer, an animal fight, a boat sailing on the river, and the typical flora and fauna). The expanded composition has, in addition, the personification of Egypt, and celebrations and processions of the Nile Festival held in honour of the flooding of the river. In other cases only details from the composition appear, such as the vegetation typical of the Nile River environment, and architectural depictions (Hachlili 1998; Habas 2005: 340-343; Michaeli 2013).

The Byzantine artists took up the rich Nilotic depiction that had developed in the Hellenistic period and had become a popular genre in the Roman period ${ }^{6}$. Cities and people engaged in fishing are often depicted, and pygmy people provide a humorous atmosphere against the backdrop of the Nile landscape. The crocodile devouring an animal belongs to the Nilotic repertoire, and is described by ancient sources (Plin. nat. XXXV.142; Timotheus of Gaza, On Animals 42: 19). From among the variety of visual depictions, I will mention Hellenistic and early Roman works such as the mosaics from Palestrina (81 BC), from the Aventine Hill in Rome, and the mosaics and frescoes from Pompeii and Herculaneum (Reinach 1922: 161, 375, 377 figs. 1-3, 5; Foucher 1965: 137139; Meyboom 1995: 20-42 figs. 6-29, 47; Tammisto 1997: 48-68 pls. 16-22, 24-28; Empereur 2000: 16 fig. 22). On mosaic floors of North Africa in the second and third centuries, the Nilotic landscape is depicted as a panoramic view, including details of the fauna (cranes, herons, ducks, fish) and the flora (lotus and papyrus), genre scenes, celebrations and rituals, like the mosaics in El Alia, Zliten and El Djem. At the same time, and against the background of the Nilotic landscape, there are humorous episodes with pygmy people hunting, fishing, and sometimes even preyed upon by a crocodile, as in the mosaics from Sousse, Timgad, Tripolitania, and also in Italica and Alcasaba in Spain (Lafaye 1911: nos. 82, 93; Foucher 1965: 138-141 figs. 4-9, 13-16, 18; Dunbabin 1978: 17, 48, 87, 109-110, 257-258, 269, 275, 278 pl. III fig. 6; Freijeiro 1978: 30-32 lám 18-19 núm 9; Fradier 1994: figs. on pp. 74-75; Dunbabin 1999: 146 fig. 152). The personification of the Nile appears in a tomb at Carthage, along with putti and fruits of the season, while in the bathhouse at the 'Nile Villa' in Lepcis Magna, the Nile god rides a hippopotamus and holds a cornucopia in its hand symbolizing the abundance and fertility of the river (Foucher 1965: 137-138 figs. 1-2; Dunbabin 1978: 126, 138, 250, 264). The Roman depictions of the Nile, in addition to their decorative quality, express a symbol of the abundance and fruitfulness bestowed on humans by the River Nile.

6 It originates in Alexandrian research literature such as the Topography of Demetrius; the Aigyptiaka of Manetho the Egyptian priest in Heliopolis; "On the Egyptian" of Hecataeus of Abdera, as quoted by Diodorus Siculus; "Journey Up the Memphis River" by Amomatos; and the literary genre of the Nilotica that described the Nile and the fauna found on its banks. Brown saw the Nilotic subject as an exotic topic that actually developed outside Alexandria, since not many works were found there (Brown 1957: 88; Meyboom 1995: 372-373; Tammisto 1997: 45, 61, 251). 
As mentioned, the Nilotic landscape continues in the art of the Byzantine period, and I will focus on depictions on mosaic floors in the Holy Land. A panoramic view extending over a wide carpet that includes the Nilometer and the Nilotic landscape, as well as walled structure with towers, a pavilion, and the characteristic fauna and flora, including birds struggling against snakes, is depicted on the mosaic floors of the transepts of the Church of the Multiplication of the Loaves and Fishes at Tabgha (Schneider 1937: 58-63, 68-73, 78-79 tables A-B, 2-17, 30-31, 68; Whitehouse 1979: 140-141, M46); and in a rich composition in the 'Nile Festival Building' at Sepphoris, which includes a male personification of the River Nile, reclining on a hippopotamus and holding a cornucopia, accompanied by five putti, two of them engraving the number IZ on the Nilometer which express the optimal and successful yearly rising of the Nile (semesion). There is also a female personification of Egypt leaning on a basket of fruit and holding a cornucopia, as well as the city of Alexandria, the Pharos, the lighthouse of Alexandria, with a flame at the top, and the arrival of Semasia to Alexandria to announce that the flood has reached its peak, at the head of a procession of horsemen approaching the city to celebrate the festival of the inundation of the Nile promising a successful crop, along with crocodile and animal combat, a cow attacked by crocodile, a sailing boat with a man and winejars, fish, birds, and lotus flowers (Netzer-Weiss 1992a; 1992b: 76-79 figs. on pp. 75-80; 1995: 166-171; Weiss - Netzer 1996: 128-131 figs. 60-64; Weiss - Talgam 2002: 61-73 figs. 2, 5-11). The walled cities of Alexandria with the Pharos and Memphis appear in special panel in the centre of the nave of the Church of Sts. Peter and Paul at Gerasa, where the river view is concise and includes only lotus flowers (Biebel 1938: 333-336 pl. LXXV: a; Crowfoot 1938: 251-254 plan XXXIX; Piccirillo 1993a: 292 figs. 554, 556). The central panel of the nave of the church at Umm al-Manabi contains a walled city, the personification of the Nile, a Nilometer, a boat, and fish (Whitehouse 1979: 141-142, M47; Piccirillo 1993a: 341 fig. 752). Part of a Nilotic landscape has survived in the hall of chapel A at Zay al-Gharby: the composition contains two sail boats, with two figures in one of the boats, and a crocodile, fish, and aquatic birds are shown in the waves of the river (Piccirillo 1993a: 324 figs. 660, 670, 672, 676). A Nilotic panel is integrated within the geometric aisle in the church at Khirbet Madras, with birds, fish, nymphaea and lotus flowers (Ganor et al. 2011: 118 fig. 15; Zissu et al. 2016: fig. 17b).

The Nilotic landscape is common, as well as a decoration of frames and borders, in villas and churches, such as at El-Maqerqesh along with hunting and pastoral scenes (Beth Guvrin; Vincent 1922: 265, 272 pl. X:4; Schneider 1937: 70-72 ills. 12-14); in the later mosaic of the Dionysius Villa at Sepphoris with water plants, naked hunting figures, a crocodile, birds, and lotus flowers (Netzer - Weiss 1994: 37; Hachlili 1998: 107 fig. 5); in the chapel of Haditha together with a depiction of a walled city, ЕГҮПТО - Egypt, people sailing on the river, and typical Nilotic flora and fauna (Avi-Yonah 1972: 118-120 pls. 20B, 21-23B; Whitehouse 1979: 138-139, M44); the walled city of Alexandria accompanied by two Nilotic scenes in the mosaic of the Church of St. John (AD 531) at Gerasa (Biebel 1938: 350-351 pl. LXVIIc; Piccirillo 1993a: 288 figs. 535, 542); in the Church of St. Stephen (AD 756) in Umm al-Rasas, including depictions of a river with fish, geese, and lotus flowers, a bird sitting in a lotus flower cup, longlegged waterfowl, boats, a crocodile, and boys fishing or hunting, as well as a series of ten cities in the Nile Delta identified by name, among them the city of Alexandria (Piccirillo 1993a: 238 figs. 345, 354-358, 380, 383, 385; 1994: 141-144 figs. 23, 29, 33-34, 58; Duval 1994: 190-191 tav. XX: 2). The Nilotic 
landscape also appears in panels in intercolumnar spaces, for example in Umm al-Rasas, in the Church of the Priest Wa'il (AD 586), where the scene includes two boats, and fish and aquatic flowers in the river (Piccirillo 1993a: 242-243 figs. 396, 398, 400; 1993c: figs. 3, 43-44, 47). In the Church of Bishop Sergius (AD 587/8), the Nilotic scene depicts two fishermen sitting on rocks and fishing, and between them a boat with oars in the river (Piccirillo 1993a: 234-235 figs. 365; 1994: 132 figs. 3, 18); and in the Church of the Holy Martyrs Lot and Procopius at Khirbat al-Mukhayyat two fantastical animals face a papyrus plant on which a duck is nesting, there are two geese on either side of lotus flowers, fish, a cormorant, and ducks swimming on a river with leaves and lotus flowers (Piccirillo 1993a: 164-165 figs. 208, 211, 215).

The Nilotic landscape is also found as a part of geometric composition, such as the birds, lotus flowers, and bird resting in a lotus cup within an octagon in Emmaus (Avi-Yonah 1934: 53 no. 346; 1992: 38 fig. on p. 38) and in the church at Kursi (Tzaferis 1983: 24-25); Nilotic motifs such as a stork and ducks resting in lotus cups in a diamond net appear in the North Church at Esbus (Piccirillo 1993a: 250 figs. 423, 433, 434), and in the Hippolytus Hall at Madaba (Piccirillo 1993a: 66 fig. 25); there is a single turtledove within two nilombos flowers in the chapel of Khirbet Munyah near Gerasa (Picirillo 1983: 355-359 figs. 2, 6, 13; 1993 a: 299 figs. 585, 589); and a single nilombos and lotus flowers decorate the geometric composition in the lower church of Quweismeh in PhiladelphiaAmman district (Piccirillo 1984: 329-340 fotos 16, 18; 1993a: 266 fig. 485). Lotus flowers decorate the western portico of the agora in Beth shean in the depiction of animals and scattered plans and bushes ${ }^{7}$.

\section{The Technique}

The density of the stone is $50-60$ per $\mathrm{dm}^{2}$, and tesserae of coloured limestone were used for the mosaic (black, dark and light brown, blue, grey, white, red, reddish, orange and yellow), as well as coloured glass tesserae (blue, green, greenish, yellow, brown and red). The use of uniformly-sized tesserae and the laying of the background tesserae in horizontal rows emphasizes the flatness of the floor (Talgam 2014: 162).

\section{The Meaning of the Descriptive Depictions}

The depiction of Odysseus and the Siren in a Jewish context has been discovered so far only in the House of Leontis. A Jewish interpretation of the subject is unknown, but in early Christian literature it was interpreted allegorically as the voyage of the Christian's earthly life, with its perils and temptations that prevent the attainment of heavenly life (Clement of Alexandria, Protrepticus 9:86-88, Stromata 6:2:89; Hippolytus, Elenchus 7:13:2, 3). In Neoplatonic thought, Odysseus' rejection of the Sirens symbolized victory over death, and this theme appears on early Christian sarcophagus lids. But it should be noted that in the mosaic of the House of Leontis, Odysseus is looking at the Nereid, and not at the Siren playing the flute as in traditional depictions. While the Sirens are a symbol of evil forces, the Nereids are symbols of immortality associated with the conduct of happy souls. Roussin $(1981: 15-16,18)$ suggests that the substitution is deliberate, and that its purpose is to express the journey of the soul into the world to come - thus the scene of Odysseus and the Siren can be interpreted as an allegory of the passage from this world to the next, and the inscription indeed seeks God's help for the landlord and expresses his wish

7 The excavations have not yet been published. My deepest gratitude for pictures and cooperation to the excavators Gaby Mazor and Walid Atrash, IAA. 
for salvation. Odysseus and the Siren, and maybe the Scylla episodes near the inscription, should be understood in an allegorical interpretation - therefore, the battle against monsters and asking God for help.

Nilotic depictions are popular in the eastern basin of the Mediterranean, and originated from the Hellenistic Roman prototypes, but in the Byzantine period they lost the ritual significance of the Nile (Balty 1984: 827-834; Piccirillo 1993a: 34; Hamarneh 1994: 235). However, both the depiction of the 'Nile Festival Building' at Sepphoris, and the Talmudic literature indicate that the Byzantine population was still aware of the cult, and the Jewish sources connect the Nile events to the theatre (Dvorjetski - Segal 1995: 100-105, and references there). Some scholars have seen the Nilotic depictions as exotic decorative scenes taken from pattern books, without symbolic meaning (Dauphin 1978: 408-409; Hachlili 1998: 119); Biebel (1938: 302, 342-349) explains the introduction of the subject into the churches of Gerasa in order to add beauty to the mosaic floors; Hamarneh (1999: 185, 188-189) notes the richly decorative character that attracted the attention of the donors, and referred only generically to elements of creation, becoming purely decorative compositions. Some researchers state that Nilotic motifs were themes of geography and topography, with no symbolic meaning, that were part of the Renaissance that took place in the time of Justinian (Kitzinger 1965: 10; 1976: 52, 54, 59; Michaeli 2013: 130), while Avi-Yonah suggests (1972: 121-122) that for Greeks and Romans, the Nilotic scene represented the exotic landscape of Egypt, but in the Christian perception the Nile valley represented earthly delights, part of the earth-bound world. Contrary to these approaches, other scholars have given symbolic explanations, since in antiquity the Nile Valley was a symbol of the prosperity of nature and fertility, appearing also in ancient sources (Hdt. 2.14), and the annual flooding turned Egypt into the granary of the Roman world (Lewis 1983: 111). A similar explanation can be given for the depictions of fishing, and sailing ships laden with wine jars, while the appearance of the walled cities is explained by Hunt (1994: 111) as a prayer for continued prosperity. According to the Christian conception, the Nile was one of the four rivers flowing from Paradise, thus the Nilotic scenes have been considered as Paradise on earth and sacred geography (Alföldi-Rosenbaum - Ward-Perkins 1980: 51; Piccirillo 1993a: 37). Maguire (1987: 43-44, 50-55, 81-84; 1999: 179-181), relying on ancient sources, considers the Nile as bringing fertility and prosperity, both material and spiritual, and as a sign of earth and water; he explains that they have allegorical meaning in connection with the creation, and the geographical role of the four Rivers of Paradise. The same interpretation is expressed by Meyboom (1995: 77-90) when he analyses the Palestrina mosaic (second century BC) - the scenes of the Nilotic landscape were perceived as symbols of fertility resulting from the flooding of the Nile, and in Christian period they were understood as illustrations of the creation. Weiss and Talgam's (2002: 72) interpretation of the mosaic at Sepphoris takes both approaches that the Nile was chosen because of its fertility, abundance, and prosperity, but also because of its exotic-decorative value. The Nile as a symbol of spiritual revival and as metaphor for wealth explains its long existence and prevalence in both secular and religious contexts, especially for people who lived in a desert or semi-desert country, and the idyllic landscape is actually heavenly bliss on earth (Foucher 1965: 143; Alföldi-Rosenbaum 1975: 152; Alföldi-Rosenbaum - Ward-Perkins 1980: 5, 49, 51; Maguire 1987: 42, 44, 51). Alföldi-Rosenbaum (1975: 151) also explains the theme as a symbol of the struggle between good and evil.

The flora (lotus, papyrus, oleander, reed) and fauna (cormorants, doves, ducks, 
geese, herons, cranes, crocodiles) of the Nile, beyond being decorative-exotic motifs, express the richness of nature and the hope for fertility and prosperity, as mentioned. The crocodile was a characteristic and sacred animal in Egypt, and although the religious-ritual aspects of Nilotic descriptions are absent from the depictions in the Holy Land, other than the unusual depiction in Sepphoris, it was considered in Roman period as part of the Nilotic repertoire, and was symbolic of Egypt, and for Christians it was a symbol of the powers of evil (Alföldi-Rosenbaum 1975: 152; Alföldi-Rosenbaum and Ward-Perkins 1980: 51). Roussin $(1981: 6-9,12,18)$ gives an eschatological interpretation to the crocodile - cow/ox combat by drawing a parallel with the combat between Leviathan and Behemoth according the Jewish tradition - one is a creature that belongs to the sea and the other to land (Job 40; Isaiah 27; Midrash Rabbah, Leviticus 13:3; Babylonian Talmud, Baba Batra 74a, 75a). This battle will take place in the End of Days, and after it the Messianic Era will be celebrated by a banquet, at which the righteous will eat the Leviathan and Behemoth. She also explains the duck in the hand of the personification of the Nile as the goose that will be provided at the Messianic banquet (Babylonian Talmud, Baba Batra 73b-74a). So, both panels - Odysseus and the Siren and the Nilotic depiction are united in the same idea of expressing hope for salvation in the End of Days.

\section{Prayer Hall or a Small Synagogue}

The second hall, excavated by D. Bahat and A. Druks (Bahat 1972; 1981; Ovadiah - Ovadiah 1987: 36-37), probably served as a prayer hall or a small synagogue, and is arranged in an unclear plan and a different orientation. This part of the complex lies to the east of the gates in the city wall, apparently on a street leading to one of them. The prayer hall is square in plan, $7 \times 7 \mathrm{~m}$, decorated by a mosaic floor (Figs. 1, 6,7). There were probably benches around the hall, which explains the distance of the mosaic from the walls of the room. The mosaic floor has been partially preserved ${ }^{8}$.

Figure 6 Plan of the Synagogue (after Bahat 1972: plan on p. 56).

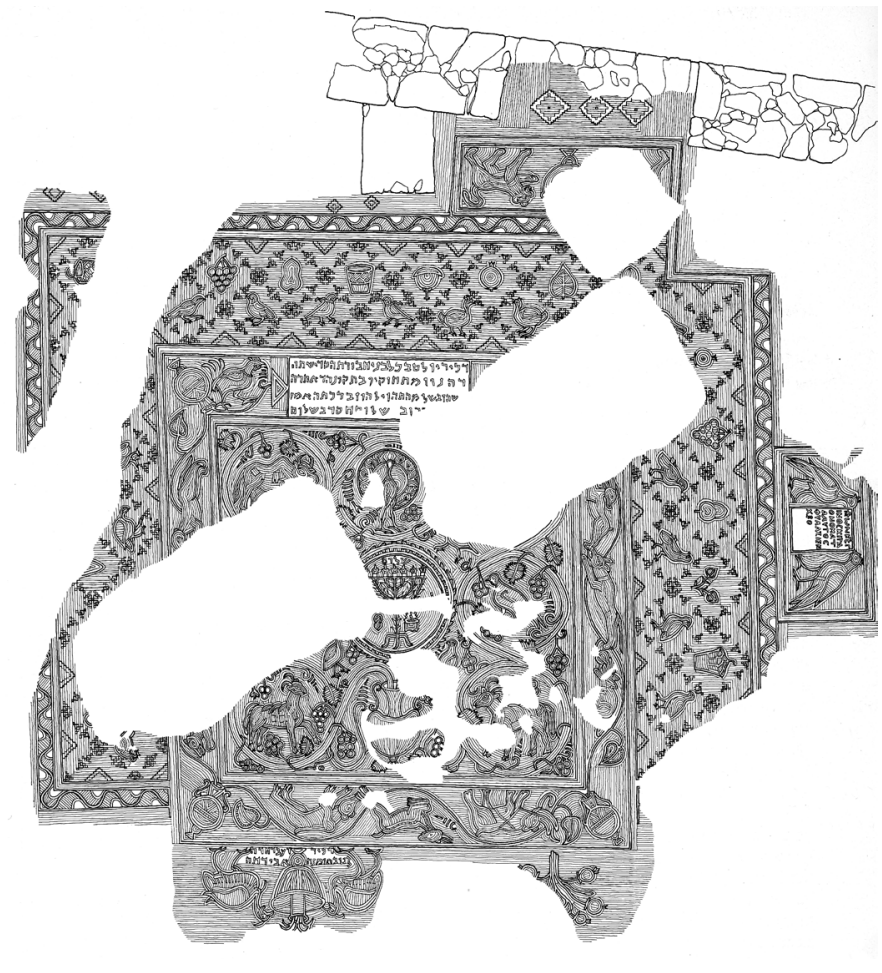

8 The mosaic floor is displayed now in the Hecht Museum, University of Haifa. My deepest gratitude to Shunit Mermelstein and Peri Harel for their help and cooperation. 


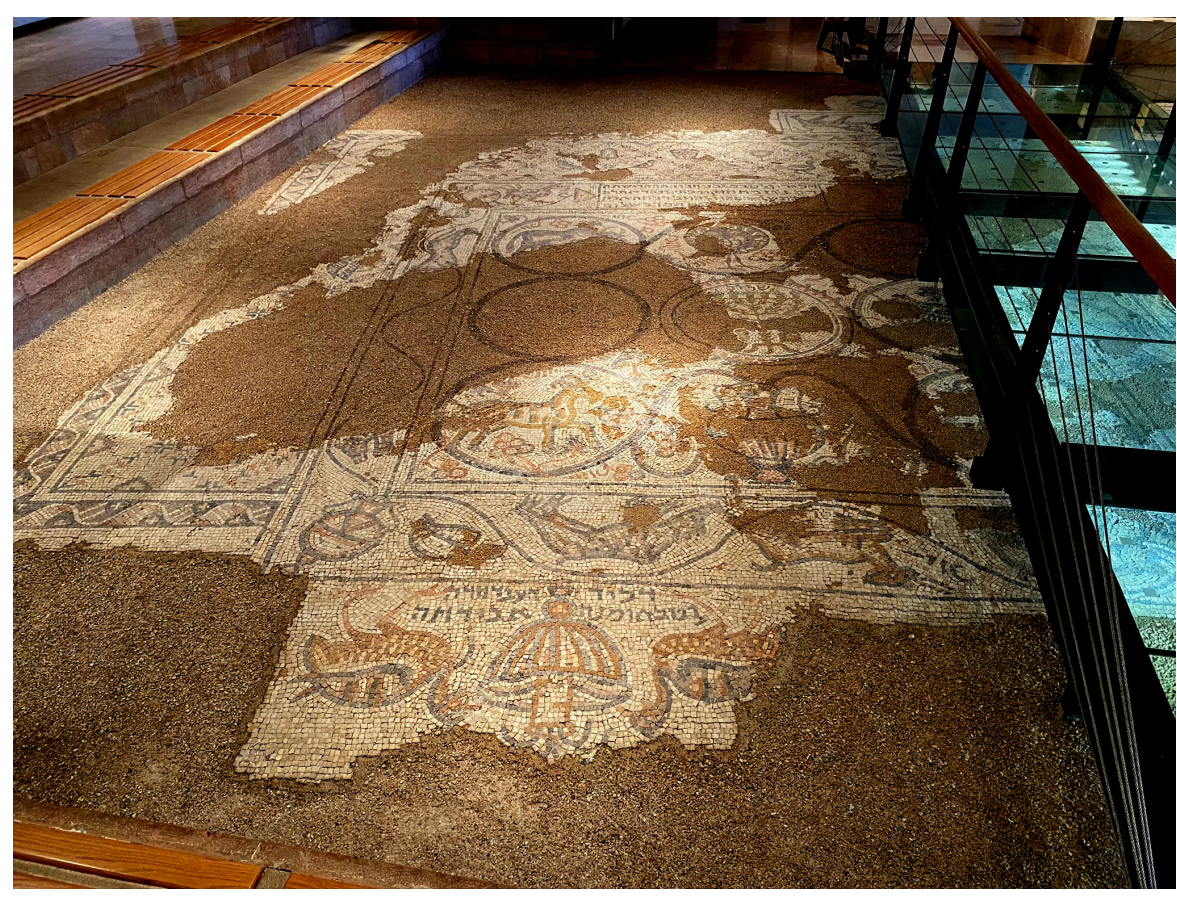

The hall has two entrances, on the north and the east, and a pair of animals decorated the two thresholds.

On the northern doorway (Figs. 8.1-8.2) the white margins are wide, and decorated with row of serrated polychrome diamonds (Avi-Yonah 1933: Type E; Décor I: pl. 5a; Ovadiah - Ovadiah 1987: Type D). Of these, three diamonds remain, formed by a black outer contour with pink and white stones inside, and four black stones in the centre. Nearby is the threshold panel, surrounded by a simple frame consisting of a row of black stones, three rows of white, and a row

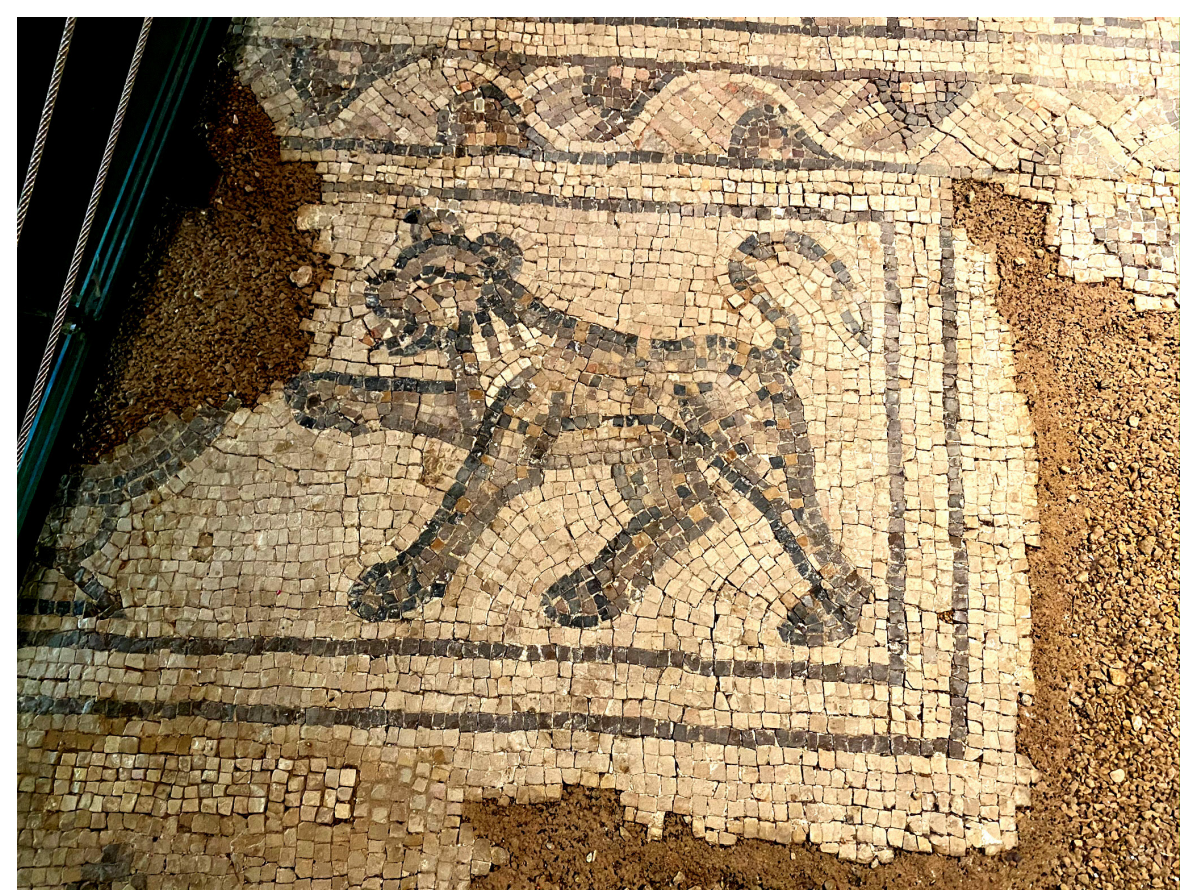

of black. The panel depicts two lion-cubs flanking a chalice, in heraldic array. The right one has survived intact while only the back paw has survived of the left cub. The lion cub raises one front leg towards the chalice, and its tail turns
Figure 7

The mosaic floor of the Synagogue (Photo: Lihi Habas).

Figure 8.1

Panel of the northern doorway: pair of lioncubes flanking a chalice, right side (Photo: Lihi Habas). 


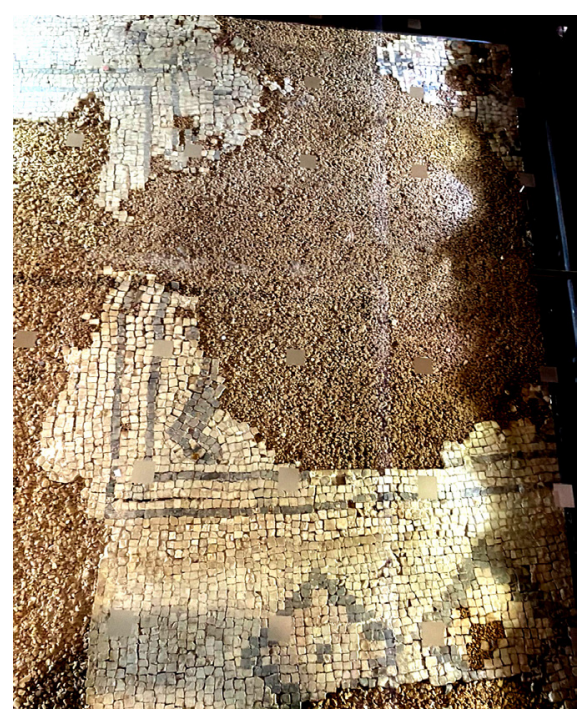

Figure 8.2

Panel of the northern doorway: pair of lioncubes flanking a chalice, left side (Photo: Lihi Habas). up and twists towards the corner. A black line forms the outline and details of the body. Rows of grey, light brown, orange, and black dots fill the body. The ears are small and round, a rounded black line forms the upper eyelid, the pupil is black on a white background. The mouth is open, the teeth are white triangular stones, and a red tongue protrudes. The neck is short and designed in diagonal black/brown and white lines. Only the lower part of the chalice has survived, shaped in black outline with a triangular base, above which is a kind of button that connects to the round body of the cup. The panel with the lion cubs and calyx faces the viewer entering the prayer room from the north. In the design of the background, it can be seen that one row follows the outline of the lion cubs and the chalice, and the rest of the rows are laid horizontally.

The threshold panel is surrounded by a simple frame consisting of a row of black stones, three rows of white, and a row of black. Set in a panel and within a simple frame of a row of black stones is a Greek dedication inscription of anonymous donors between two pheasants $(34 \times 45 \mathrm{~cm}$ ), in black letters (Fig.

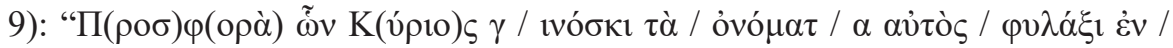
$\chi \rho o ́(v \omega)$ " - "The gift of those of whom the Lord knows the names, He shall guard them in times ...' (Bahat 1972: 58; 1981: 85; Roth-Gerson 1987: 41-43 fig. 16, no. 9) ${ }^{9}$. According to the excavators this inscription was inserted at a later time, since the frame cuts into the beaks and tops of the birds. The lower part of the inscription has been removed and replaced by plain and cruder tesserae.

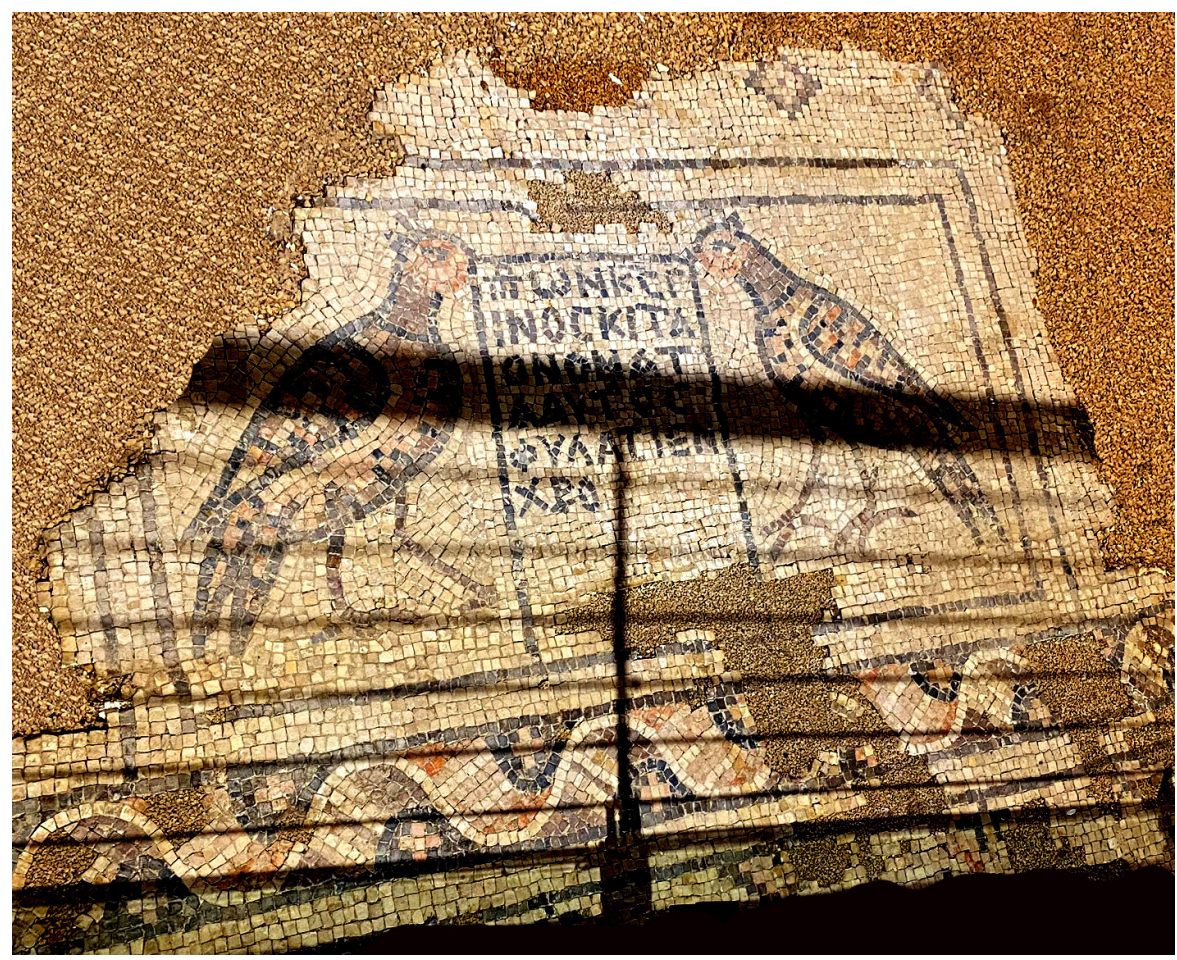

The pheasants are depicted in profile, and are designed in the same way: the body, wing and tail are outlined in black. The head is decorated with pink stones, the upper eyelid is black, and the pupil is black on a white background. The neck is brown and separated from the body by a black line. The wing is highlighted

9 Anonymous donors are common in Hebrew and Aramaic inscriptions, and appear in the synagogues at Hammath Tiberias, Husifah, Ma'on, Na'aran and Jericho (Naveh 1978: 48, 66-68, 92-93, 103-105 figs. on pp. 48, 66, 92, 104, nos. 6, 26, 39, 57, 69; Foerster 1981: 12 note 2), and in Greek inscriptions such as the marble panel from Caesarea (Roth-Gerson 1987: 111-112 fig. 57 no. 25). 
and separated from the body by a black outline and a white line, and is designed in short and irregular rows of stones in black, pink, light brown, and beige. The body is shaped by curved rows of pink and a row of brown with scattered black stones. The legs and claws are brown. The panel with the inscription and the pheasants faces the person going out of the prayer hall.

The south margin is partially preserved: on the right side are a pair of guineafowl in heraldic array, flanking a chalice or bowl from which a plant is growing, and accompanied by an Aramaic inscription: "Remembered be for good the artisan who made this work" (Figs. 7, 10) (Bahat 1972: 57; 1981: 85; Naveh 1978: 78-79 fig. on p. 78 no. 47). On the left a pomegranate tree survives.

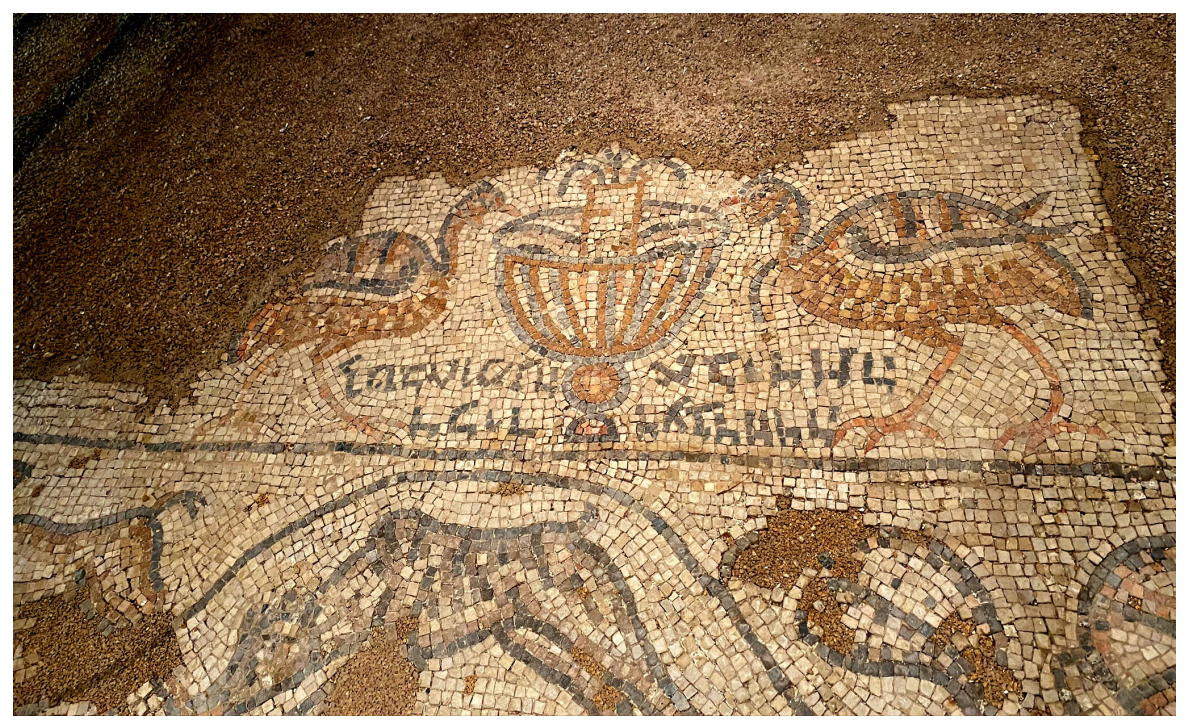

A black contour shapes the upper body, head, neck, wing, and tail of the guineafowl, while a light brown contour shapes the lower part of the bird. The head, open beak and neck are light pink-brown, and the pupil is black on a white background. Vertical rows in white, pink, black, brown, and beige fill the wing, and a row of white stones separates the wing from the body. Short and irregular rows in brown, beige, and pink fill the bird's body, and the legs are orange. A black outline shapes the chalice and its parts: the base is semi-circular in pink and white, and a round button in the same colour connects the base with the vessel's polygonal body, which is shaped in black, pink, white, and orange rounded lines. The inside of the cup is depicted in a $3 / 4$ view, so that its contents can be seen, formed by diagonal rows of black, white, beige and pink, and in the middle a column rises up, from which black branches grow. The trunk and branches of the pomegranate tree are black, and the reddish pomegranates are sprinkled with white stones. The two lines of the Aramaic inscription extend between the legs of the birds and the base of the vessel. The letters are black, and it is to be read facing north, by contrast with the other depictions that face south.

The hall itself is decorated with vine scrolls populated by animals, surrounded by several borders. The outer frame is narrow and encompasses only three sides (east, north, and west), decorated with a three-dimensional, undulating, polychrome ribbon in frontal perspective on a black background (Fig. 11) (AviYonah 1933: Type B1; Décor I: pl. 65a; Ovadiah - Ovadiah 1987: Type B1). The outline of the ribbon is bounded by two rows of black stones, and is formed by a white/pink outer stripe, the outer part is rows of diagonal stones in red, pink, white, and brown, and the inner part is diagonal rows of stones in dark brown and light brown, white, and light pink. Between them and on the black background are small pink flowers with a white stone in the centre.
Figure 10

The south margin: pair of guinea-fowl flanking chalice or bowl and Aramaic inscription (Photo: Lihi Habas). 
Figure 11

The outer frame: undulating ribbon

(Photo: Lihi Habas).
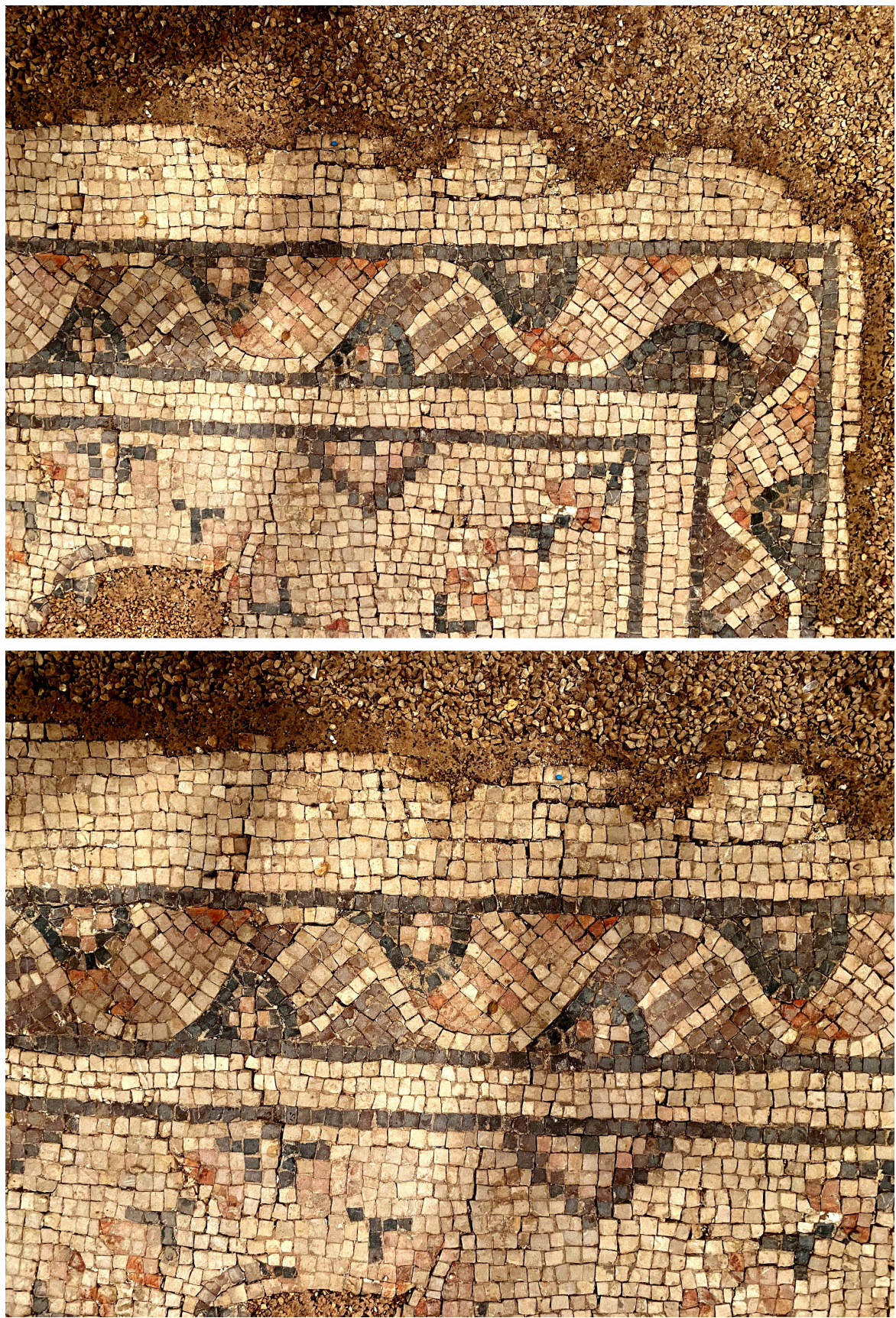

The middle frame also encompasses the same three sides. It is composed of a simple frame of black and white rows, and inside, a wide frame decorated with a diamond network made of buds, with four buds in the shape of open flowers formed at the meeting points (Décor I: pl. 15j; Ovadiah - Ovadiah 1987: Type H7). The net is populated with birds (guinea-fowls, doves, and beribboned parrots with a ribbon tied to the neck and waving in the wind), fruit (pomegranates, citrons, cluster of grapes), baskets of fruit, lotus flower, leaves, and serrated triangles (Figs. 12.1., 12.2, 13.2). The buds are made of a black calyx and a reddish-pink blossom. The serrated triangles are designed with a black outline, and the interior is varied: brown and white rows, or brown stones in different shades, grey, pink and white. A black outline shapes the body of the guinea-fowl, the wings and tail, legs and beak are in a light pink/brown colour, a checked pattern of black and white/beige shapes the wings, and a white line separates the wings from the body. A black contour shapes the birds' bodies and 

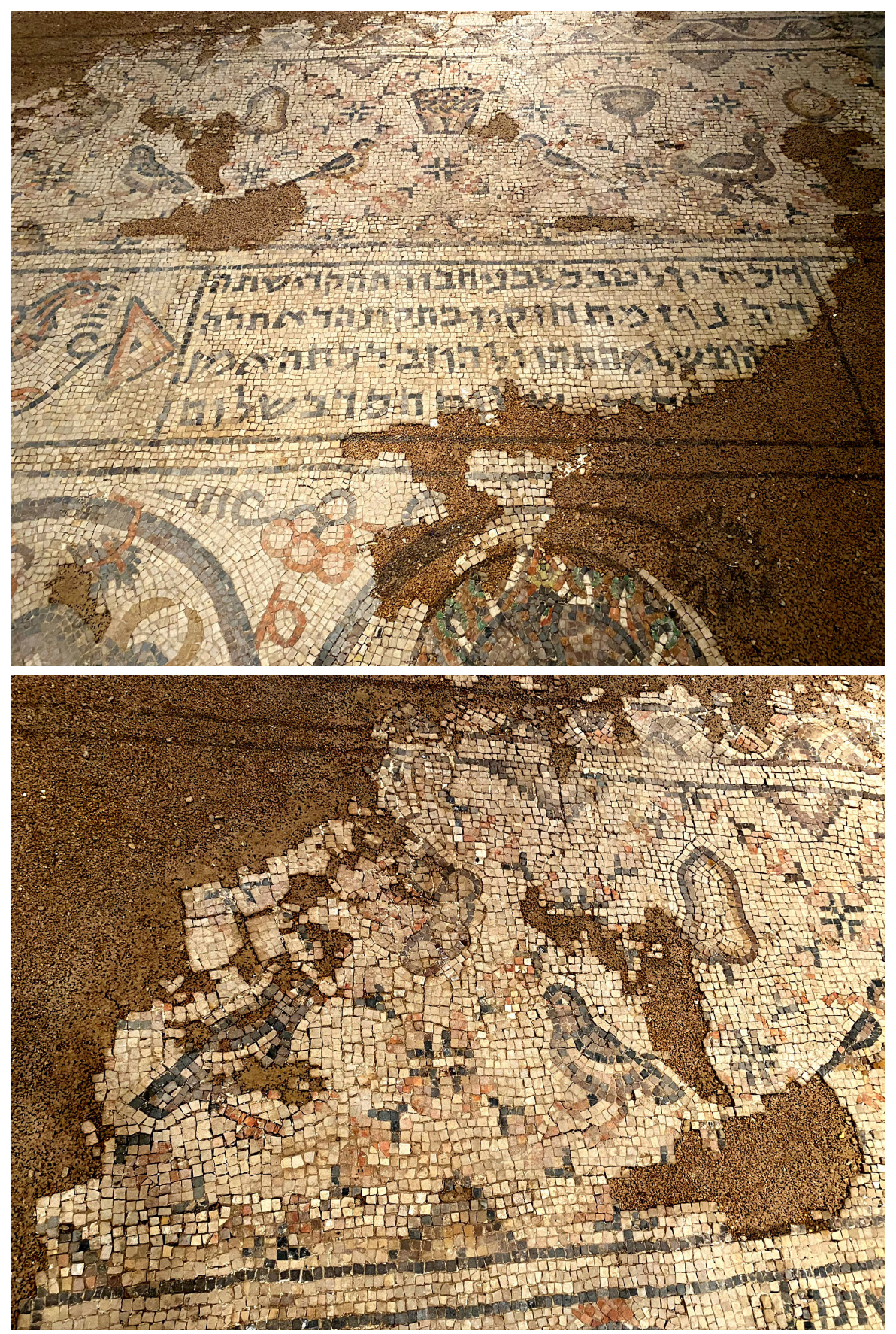

wings. The head and wing are light brown in colour, with eyes formed by black and white triangular stones, and a white row separates the wings from the body. The body is designed in pink, brown, and grey rows with black stones, and the legs and beak are pink. The beribboned parrots are similarly designed with a pink ribbon, and there are also birds with a tassel on their head. The fruits are outlined in black/brown and are gradually filled with rows of pink, grey, yellow, and white/beige stones. Some of the woven baskets are empty, some are full of bunches of grapes, and others have a handle: black lines shape the patterns of the woven baskets with rows of pink and white stones. A black outline shapes the lotus flower and the interior with grey and brown stones and a beige centre. A brown contour shapes the pomegranate and interior in concentric rows of red and beige.

The inner frame surrounds the carpet all sides: there are four amphorae at the
Figures $12.1-12.2$

The middle frame: populated diamond network (Photo: Lihi Habas). 
Figure 13.1

The inner frame: amphorae at the corners and a rooster (Photo: Lihi Habas).

\section{Figure 13.2}

The inner frame: undulating ivy branches populated with animals chasing scenes (Photo: Lihi Habas). four corners, laid diagonally (Figs. 6, 13.1), from which undulating ivy branches with tendrils issue in either direction (Décor I: pl. 64d). Among the leaves there are animal chase scenes, including a dog chasing a hare, a fox chasing a fawn, a bear chasing a fawn, and an elephant (Figs. 13.2 - 13.3). In the middle of the northern part of the frame is a large Aramaic inscription in a tabula ansata, 47 x $140 \mathrm{~cm}$, flanked by a pair of roosters, of which only the left has survived: "Remembered be for good all the members of the Holy Congregation who endeavoured to repair the holy place. In peace shall they have their blessing, Amen! ... Peace! Piety in peace!" (Figs. 12.1 - 13.1 top) (Bahat 1972: 57; 1981: 85; Naveh 1972: 186 figs. on pp. 186-187, no. 184; 1978: 77-78 fig. on p. 77 no. 46). The reading direction of the inscription is from south to north, and it can be read from the centre of the carpet.
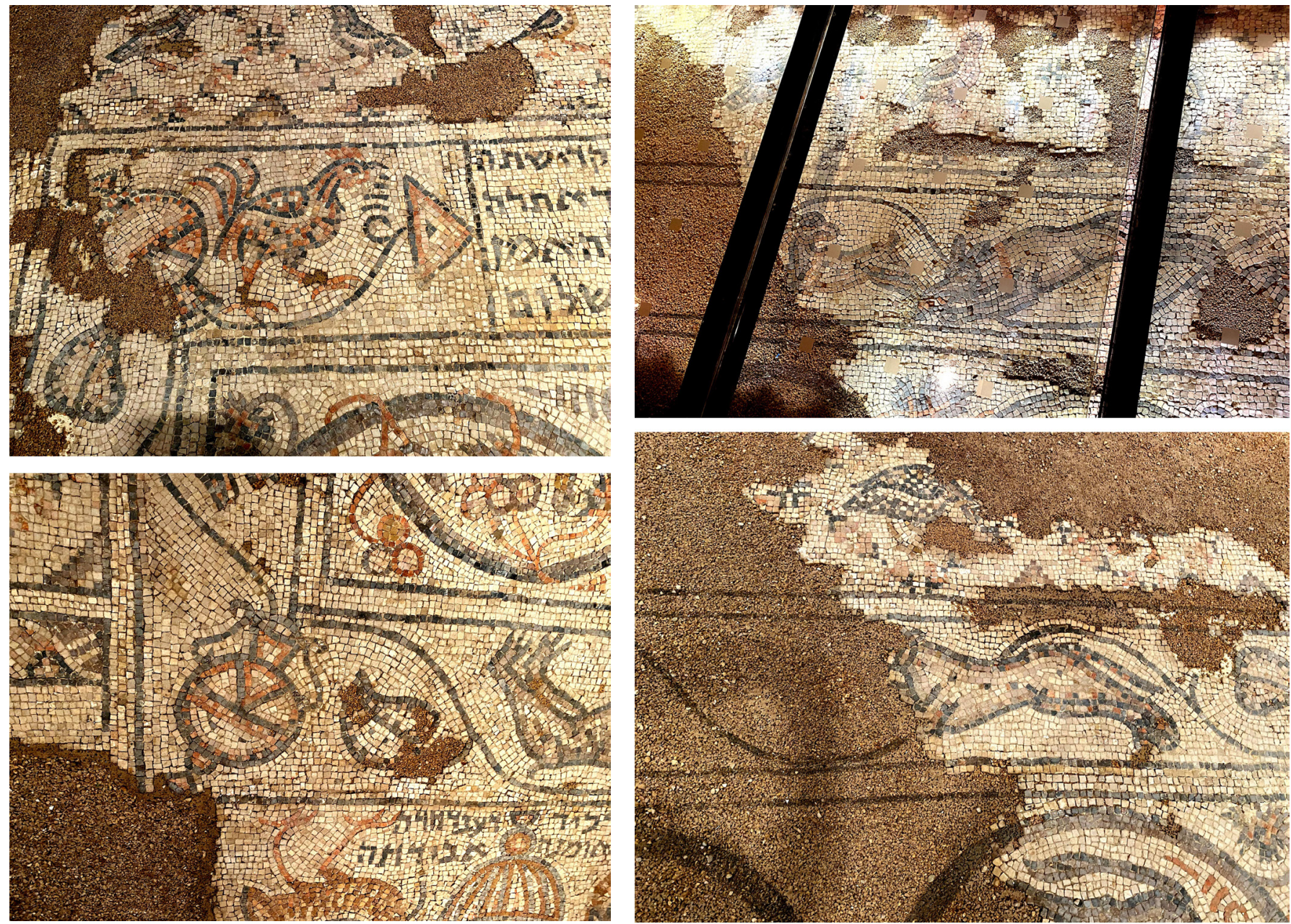

The ivy branch is a simple black outline. The leaves are shaped by a black line and a central stripe, a row of alternately black and pink stones follows the outline of the leaf, and it is filled with mixed white, pink, and black stones. The amphorae are simple and schematic with black contours shaping the triangular base, a semicircle connecting the base to the spherical body, neck, and rim of the vessel. Two amphorae have two curled handles in the form of volutes, the third amphora has no handles, and the fourth amphora has not survived. Red stones fill the base and hemisphere. A row of black stones and two horizontal pink rows divide the spherical body into two, the bottom is decorated with a row of alternating black and pink stones, a light pink row, and white rows laid in a semicircle, and the top of the vessel body is divided into three by rows of black, pink and white stones. The neck is decorated with pink and white stones. 


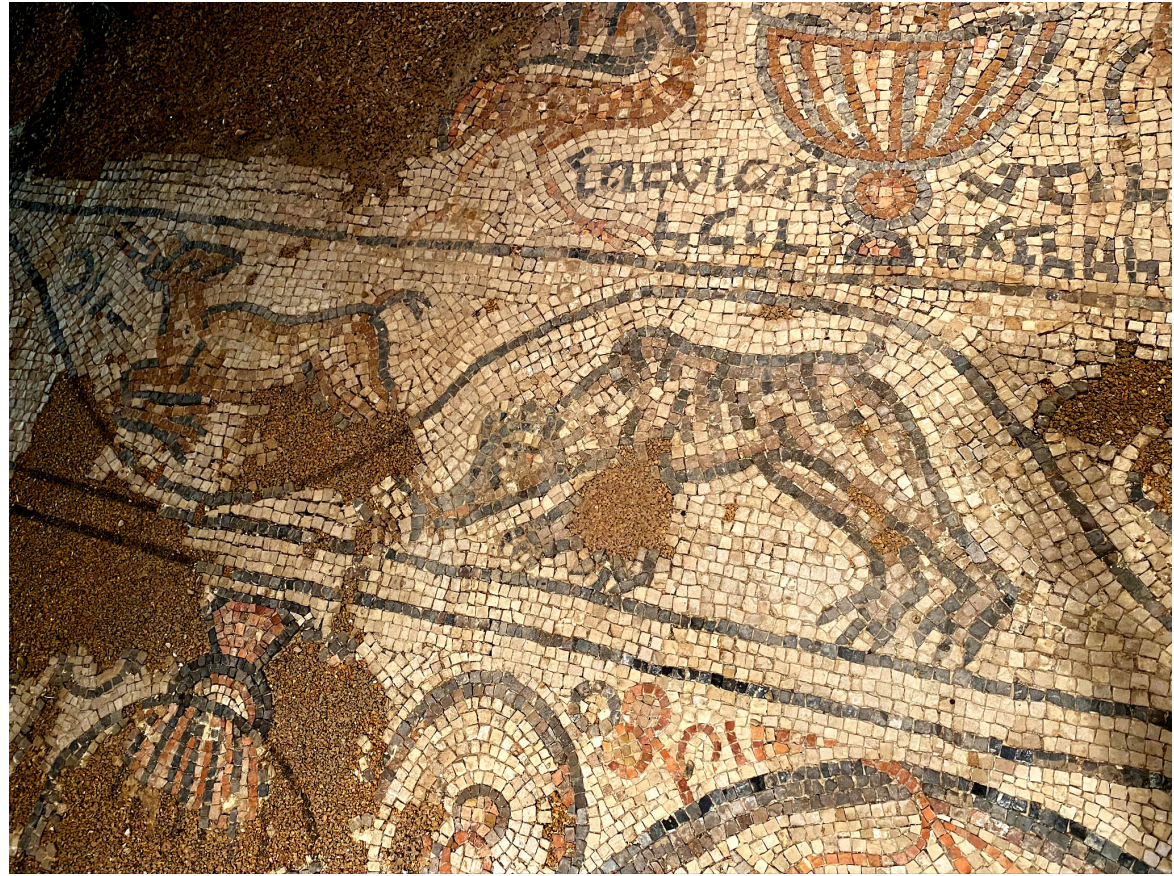

Black lines outline the body, horns, tails, and hooves of the animals. Long and short rows of grey, brown, pink, orange, white, and black shape the body parts. The design of the rooster uses black and reddish contours that shape the body, tail and wing. The face, cockscomb and legs are red. Light brown, black, white, and red stones are scattered all over the body. The animals move around, and the viewpoint for looking at them is from the centre of the carpet to the frame. The movement of the animal chase is lively, the attackers leap with open mouths and a protruding red tongue, and the victims flee, and sometimes even look back. The dog has a red collar around its neck and its teeth sink into the rabbit's hind legs.

The carpet is decorated with populated vine scrolls creating three rows, each with three scrolls (Figs. 6-7), and the viewing direction is from south to north. In the first row, the vine scrolls sprout from an amphora that is located at the middle of the southern row, flanked by a pair of goats in heraldic array (Figs. 14.114.2). In the second row is a central medallion, flanked by a pair of pheasants of which only the right has survived. This central medallion is populated with Jewish ritual objects, including a menorah (seven-branched candlestick), an ethrog (citron), a censer hanging from chains, and a shofar (ram's horn), with an inscription "peace" in Hebrew above the candlestick (Figs. 14.1, 14.3). In the third row is a peacock with spread wings in the centre, flanked by a pair of bulls, of which only the left has survived (Figs. 14.1, 14.4, 14.5).

The vine scrolls are formed by a row of black stones, and two brown/grey rows, and these form round medallions. The branches and tendrils are pink or grey, and on the twigs hang clusters of grapes and vine leaves. These fill the scrolls and spaces between them. The bunches of grapes are each designed of grapes in different colours (brown, red, pink, black) and filled with pink or beige stones or in several colours. The vine leaves are shaped from jagged leaves in black/grey with reddish veins.

Black contours outline the amphora and its parts, the triangular base is reddish, a half-button connects the base to the body of the vessel, shaped in concave white, black, grey, red, and white lines. The body of the vessel is round and polygonal,
Figure 13.3

The inner frame: undulating ivy branches populated with animals chasing scene (Photo: Lihi Habas).

Figure 14.1

Populated vine scrolls carpet: central column - amphora, seven-branched candlestick, and peacock (Photo: Lihi Habas).

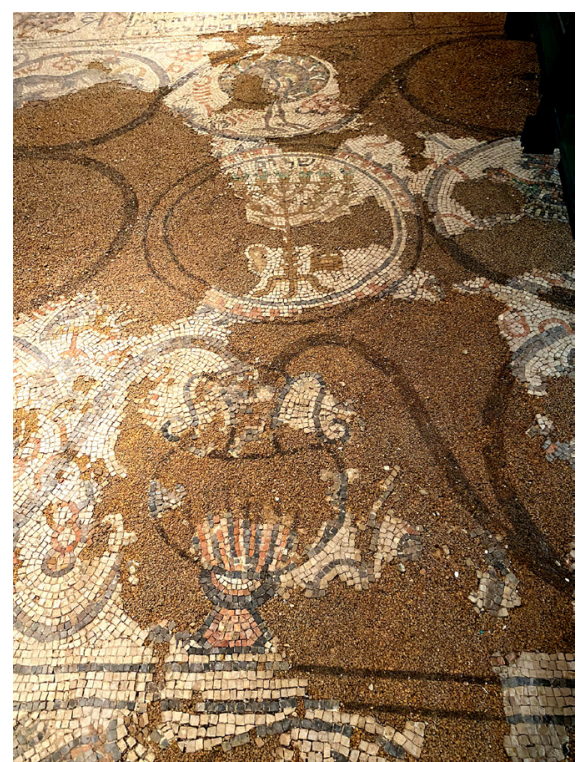


Figure 14.2

Populated vine scrolls carpet: goat (Photo: Lihi Habas).

Figure 14.3

Populated vine scrolls carpet: sevenbranched candlestick, citron, censer, and ram's horn (Photo: Lihi Habas).

and vertical rows in black, pink/beige, and red form the ribs. A horizontal black line separates the neck from the body of the vessel, and the handles are curled in the shape of volutes (Fig. 14.1). The goat is depicted in motion, a black outline shapes the wavy back, tail and front parts of the legs, and a brown/orange and yellow outline shapes the head, the small ears, front of the neck, lower body, and back of the legs. The pair of rounded horns are formed by two rows of black and orange. A black pupil is depicted at the edge of the eye on a white background. Curving rows of beige, red, brown, and black follow the back of the goat and form its upper body, while short, pink, brown, and black rows on a white background outline its lower body. The hooves are grey (Fig. 14.2).
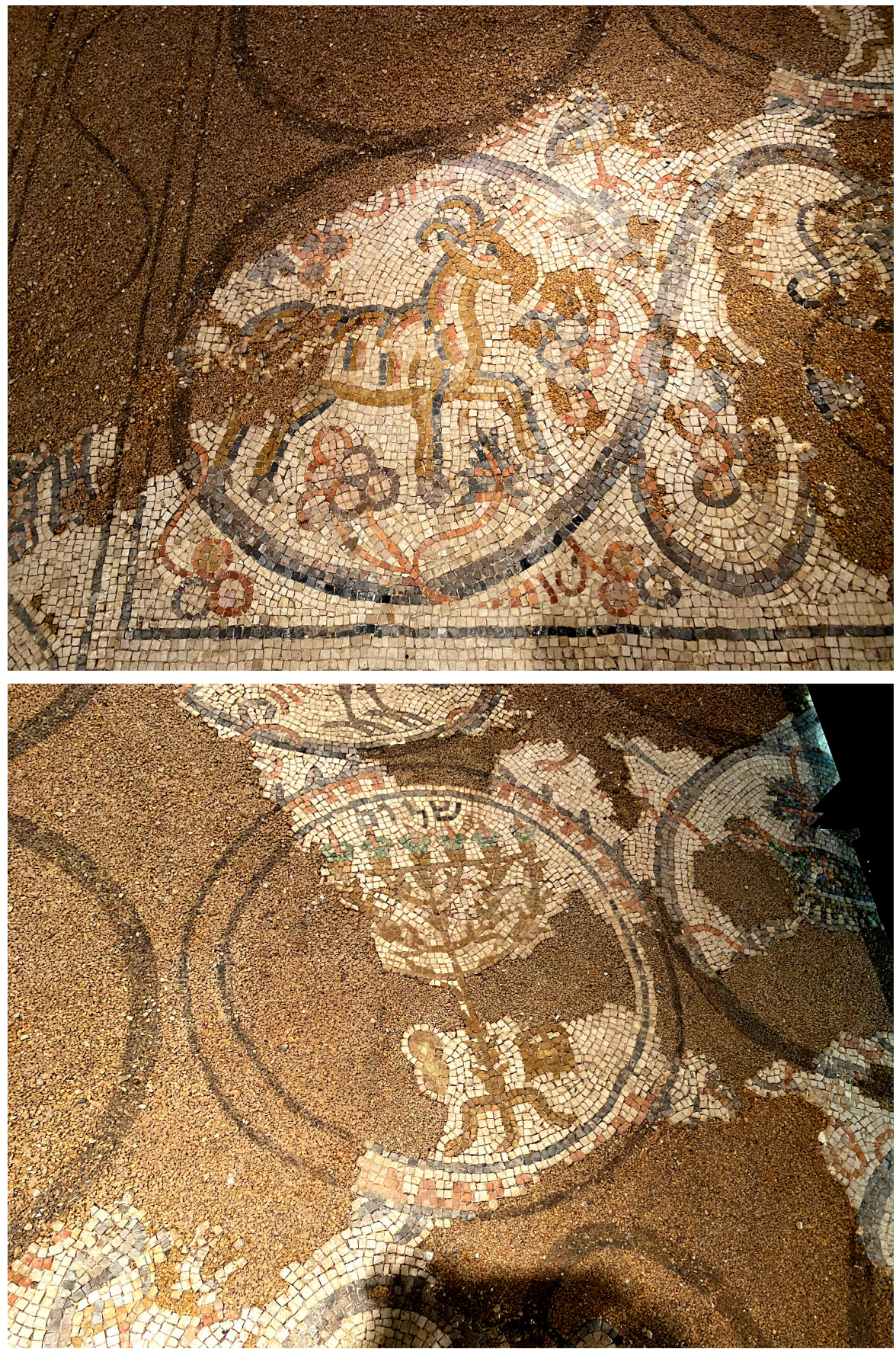

The central medallion of the second row is not part of the vine scrolls, and is made of several frames: the outer frame consists of a simple filet of black tesserae 
with black leaves facing outwards; a simple filet of red tesserae with dentils of squares of four tesserae (Avi-Yonah 1933: Type A3; Décor I: pl. 2j; Ovadiah Ovadiah 1987: Type A3); and a simple filet of black tesserae. The candlestick is made of dark and light brown tesserae, and stands on a tripod base. The stem and branches of the candlestick are made of buds, in imitation of the 'bud-andflower' pattern noted in the Bible. The branches terminate in a horizontal bar, and above this are small brown cups and green beakers from which wicks and red flames with yellow cores emerge. The letters of the inscription are black, and the liturgical objects are made of dark and light brown tesserae (Figs. 14.1, 14.3).

The pheasant's body is outlined by a red contour, the upper eyelid is black, the lower eyelid is white, and the black pupil is at the edge of the eye. A white stripe separates the wing from the body. Black, white, red, and green stones shape the wing, and the body is formed of short vertical rows in white and black (Fig. 14.3). The peacock is shown in 3/4 view, and its outspread tail surrounds its body in concentric circles. A black outline shapes its body and tail. The eye appears in the centre of the head, with a black upper eyelid and a lower red eyelid, and the pupil is green, at the edge of the eye. The neck is black-grey, the body is shaped by rows of light brown, pink and white/beige, and the legs are brown. The feathers are colourful - the base of the feathers is white and the 'eyes' are made of a black circle surrounded by a green circle made of glass, a brown/reddish circle, a black circle, and a red circle (Figs. 14.1, 14.4). A black/ grey contour shapes the body of the bull, its tail and legs. Grey and brown rows

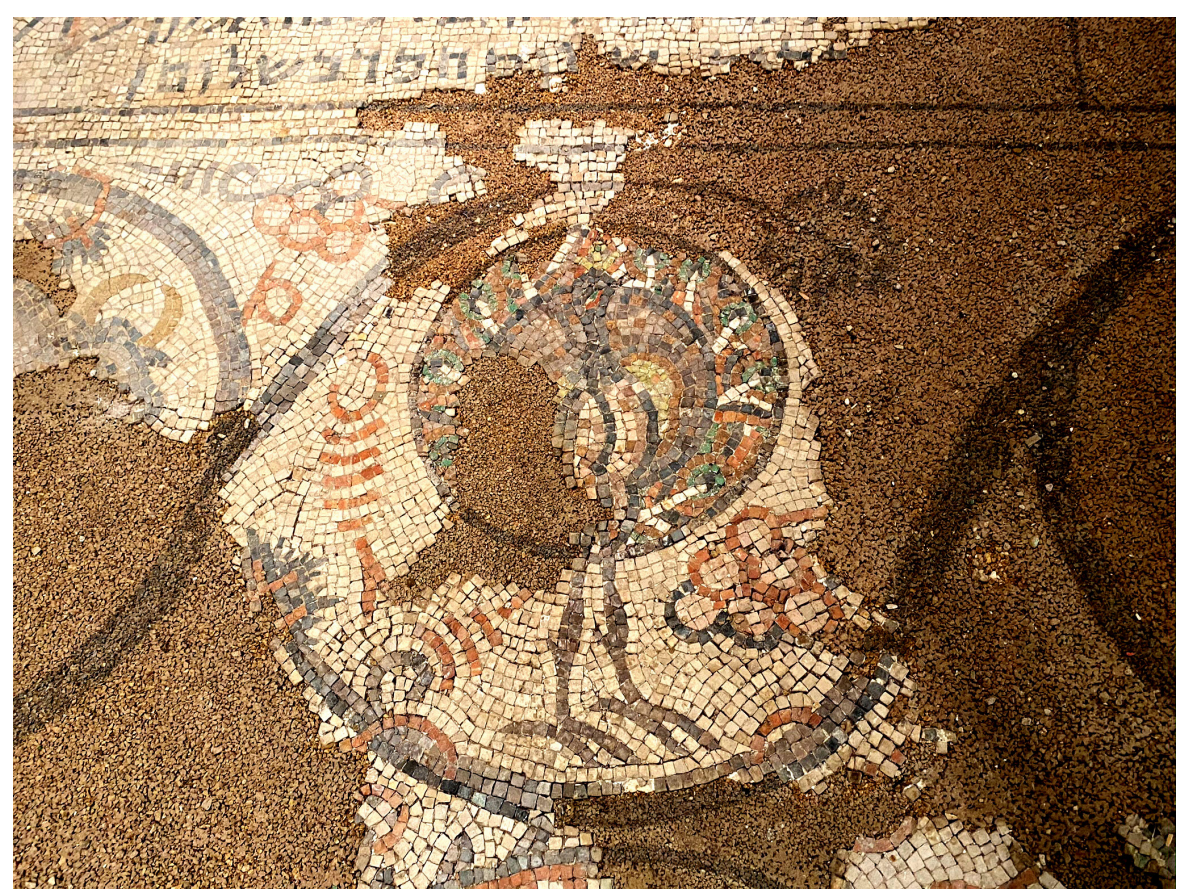

follow the upper back, thighs and lower abdomen. The body parts are separated by light brown and black lines, and between them areas of white, brown, and black. The curved horns are yellow, the small ears are black, and the pupil of the eye is black. The male genitalia are marked by a red outline with white stones in the centre (Fig. 14.5).

The design of the mosaic expresses richness and density (horror vacui), the spaces between the scrolls are filled with grape leaves, grape clusters, tendrils, and different types of birds.
Figure 14.4

Populated vine scrolls carpet: peacock (Photo: Lihi Habas). 
Figure 14.5

Populated vine scrolls carpet: bull (Photo: Lihi Habas).

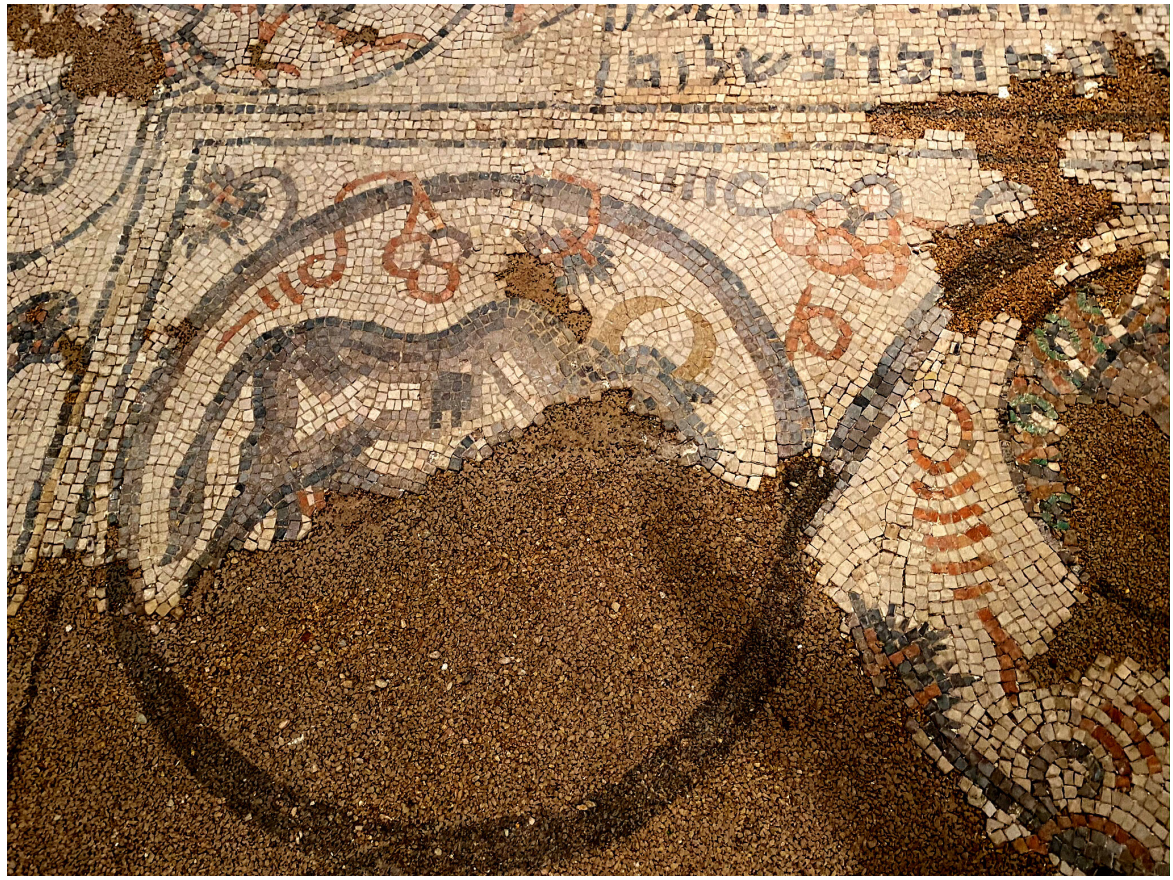

The viewpoints in the mosaic vary: in some places the threshold panels refer to the direction entering the hall, in others, the exit from it. The events of the chase scenes of the inner frame can be seen from the centre of the carpet. The populated vine scrolls containing the inscription found in the inner frame are oriented from south to north. In the southern frame, the motifs are oriented from south to north while the inscription is read upside down. These different directions of the carpet cause the viewers to move in different directions to observe the different parts that made up the composition.

\section{The Technique}

The size and density of the tesserae vary depending on location: in the northern doorstep the tesserae are square or rectangular, $1 \times 1,1 \times 1.5,1 \times 2 \mathrm{~cm}$, and triangular stones are also used for depiction of the teeth. The density of the stone is 49 per $\mathrm{dm}^{2}$. In the eastern doorstep the tesserae are square or rectangular, $1 \mathrm{x} 1,1 \mathrm{x} 1.5$, $2 \times 2 \mathrm{~cm}$, and triangular stones are also used. The density of the stone is $36-42 \mathrm{per}$ $\mathrm{dm}^{2}$. In the frame the tesserae are square, $1.5 \times 1.5 \mathrm{~cm}$, and triangular stones are also used for the eyes. The density of the stone is 49 per $\mathrm{dm}^{2}$. In the vine scroll the tesserae are square and rectangular, $1.5 \times 1.5,1 \times 2 \mathrm{~cm}$ and triangular stones are also used for the eyes. The density of the stone is 60 per $\mathrm{dm}^{2}$. Tesserae of coloured limestone (black, dark and light brown, grey, white, beige, red, reddish/ pink, orange and yellow), and coloured glass tesserae (green, greenish, yellow, and red) were used for the mosaic.

\section{The Parallels of the Motifs and Composition and Their Frequency}

The composition and the motifs of the prayer hall are common in mosaic pavements in the Holy Land in a secular and religious context. Some adorn carpets, others are in frames or appear as individual motifs.

Frames of polychrome three-dimensional undulating ribbon appear in the Church of Bishop Sergius (AD 587/588) and the Church of the Priest Wa'il (AD 586) at Umm al-Rasas (Piccirillo 1993a: 234-235, 242-243 figs. 365, 369, 396, 399-400; 1993c: figs. 15-16, 23, 47; 1994: figs. 2-3). 
Frames of populated diamond network made of buds, with four buds in a shape of open flowers at the meeting points, are very common and are populated with a wide variety of motifs (fruits, vegetables, flowers, animals, birds, and geometric patterns), as in the Monastery of Lady Mary at Beth Shean (Fitzgerald 1939: 8-9 pls. XIII, XVIII); the churches at Shavei Zion (Prausnitz 1967: plan 7 pls. XXVIII-XXIX, XL: b), Kafr Kama (Saarisalo - Palva 1964: figs. 5, 16), and Kursi (Tzaferis 1983: pl. XI: 6). In Madaba in Jordan, this network is typical of the workshops that operated in the area, populated by many motifs, and appearing in a religious context, such as in the northeastern chapel of the Church of the Apostles, and the Upper Baptistery Chapel in the Cathedral complex, as well as in a secular context, such as the Hippolytus Hall, the Burnt Palace, and the Mosaic of Birds and Fish (Piccirillo 1993a: 66, 78, 106, 118, 132 figs. 25, 49-50, 54, 90, 104, 116, 119, 162-163).

Frames of undulating ivy branches without any additional depictions appear in the church at Ashkelon-Barne'a (Ovadiah - Ovadiah 1987: 13-14 pl. III:1, no. 7); in Beth Shean in the Samaritan Synagogue, and a variant is found in a villa (Ovadiah-Ovadiah 1987: 34, 40 pls. XXIX:2, XXXV nos. 30, 42); in the south chapel at Kafr Kama with lotus flowers (Saarisalo - Palva 1964: 7 pls. 7-8; Ovadiah - Ovadiah 1987: 88 pl. C no. 138); and in the church at Sede Nahum (Ovadiah - Ovadiah 1987: 125 pl. CXXXVIII no. 212). In Jordan, such a frame appears in the Basilica of Moses at Mt. Nebo, the Central Church at Ma'in, the Church of John and Elias, and the Church of the Holy Fathers at Khattabiyah (Piccirillo 1993a: 148, 202, 244 figs. 190, 193, 314-315, 402, 405).

Pair of animals flanking an inscription: a pair of lions flanking an inscription appears in some of the synagogues, such as at Hammath Tiberias (Dothan 1983: 49 pls. 17:1, 34), Hammath-Gader (Naveh 1978: 54 fig. on p. 54), Beth Alpha (Sukenik 1932: 42 pl. XII: 1), and Na'aran (Vincent 1919: 532-563 fig. 1; 1961: $169 \mathrm{pl}$. VII).

Animal chases are a common theme in frames and carpets. Animals chasing between trees appear in a frame in the villa in Caesarea Maritima (Ovadiah Ovadiah 1987: 48-49 pl. XXXVIII:1, 3 no. 62; Spiro 1992: 250 fig. 8). In a populated vine scrolls carpet, this theme appears along with other motifs or episodes in the Synagogue in Gaza Maritime (Ovadiah 1969: 124 pl. 3; Ovadiah - Ovadiah 1987: 61 pls. LII:1, LIII, no. 83); in the church at Hazor Ashdod (Habas 2019: 103 figs. 1, 9; 2020: 116-118 figs. 10-12); in the Church of Bishop John at Khirbet Barqa (Gan Yavneh; Habas 2012: 132 fig. 1); in the church at Shellal (Trendall 1957: 20 fig. 5: b pls. I-II); in the Church of St. Stephen at Horvat Be'er-shem 'a (Gazit - Lender 1993: 275-276 figs. on p. 273); and in the Funerary Chapel at el Hammām (Beth-Shean; Avi-Yonah 1936: 15 pls. XIV$\mathrm{XV})$.

Populated vine scrolls with an amphora in the centre of the first row: the layout of a scroll sprouting from an amphora/kantharos located in the centre of the first row is defined by Dauphin as Type IV:b (1976: 116-117 fig. 2). This composition is very common, and has many parallels in the Land of Israel: in the Monastery of Lady Mary at Beth Shean (Fitzgerald 1939: 9 pls. XVI-XVII) and the Monastery of St. Martyrius in Ma'ale Adummim (Magen 1993: 179, 184 figs. on p. 179 pls. X:a, XI:a); the churches at Hazor Ashdod (Habas 2020: 112-115 figs. 2, 6), Shellal (Trendall 1957: 16-21 fig. 5:b), Tel Kerioth (Derfler 2003: 42 figs. 1, 5), Khirbat 'Asida (Baramki - Avi-Yonah 1934: 17-19 pls. X, XI:2), the Church of St. Stephen at Horvat Be'er-shem'a (Gazit - Lender 1993: 275-276 figs. on p. 273 pl. XXI:d); the chapels in El-Maqerqesh (Beth Guvrin; Vincent 
1922: 259-281; Abel 1924: 583-604), Horbat Sokho (Gudovitch 1996: 19 plan 1 fig. 1), and the Armenian mosaic in Jerusalem (Schick - Bliss 1894: fig. on p. 259), and also in the synagogue at Ma'on (Nirim; Avi-Yonah 1960a: 26 fig. 13 pls. III:1). Foerster saw the appearance of populated vine scrolls in synagogues as echoes of Christian iconography (Foerster 1988: 202-204), but in fact this composition continued from the Roman tradition to both communities.

Pair of animals flanking an amphora in heraldic array: this pattern appears in many mosaic floors: the animals are peacocks in the church at Shellal (AD 561/2; Trendall 1957: 12-21 figs. 3-4, 5: b pls. I-IV), in the Armenian 'Mosaic of the Birds' in Jerusalem (Schick - Bliss 1894: 257-261 figs. on pp. 258-259), and in the synagogue of Ma'on (Nirim; Avi-Yonah 1960a: 26 fig. 13 pls. III:1); there are lions/lionesses in the church at Hazor-Ashdod (AD 511/2) (Habas 2019: 101-103 figs. 1, 5-6; 2020: 114-115 figs. 2, 6-7), and in the Church of St. Stephen at Horvat Be'er-shem'a (Gazit - Lender 1993: 275 fig. on o. 273); there are panthers in the Church of Deacon Thomas at 'Uyun Musa Valley (Piccirillo 1993a: 187-188 fig. 263); and sheep and stags in the Church at Khirbat 'Asida (Baramki - Avi-Yonah 1934: 17-19 pls. X, XI:2) and in el-Maqerqesh (c. AD 527) (Beth Guvrin; Abel 1924: 592-598 fig. 4 pls. XIII:2, XIV).

Jewish ritual objects and their meaning: the seven-branched candlestick, citron, censer hanging from chains, and ram's horn appear in a group of synagogues in a special panel in front of the bema along with a depiction of the Ark, such as in Hammath Tiberias (Dothan 1983: 33- 39 plan E pls. 10, 25-28), Susiya (Gutman - Yeivin - Netzer 1981: 126 plan on p. 123, fig. on p. 125), Na'aran (Vincent 1961: pls. VII, XXIII), the Samaritan Synagogue at Beth Shean (Zori 1967: 152-154 figs. 3-4 pl. 29:5), and Beth Alpha (Sukenik 1932: pl. IX); they are part of an array in a rich composition in the synagogue at Sepphoris (Weiss 2005: 65-77 figs. 2, 11-15). They appear flanked by a wreath and inscription within in a frame close to the entrance in the synagogue at 'Isfiya (Huseifa; Makhouly - Avi-Yonah 1934: 120-122 pl. XLVII; Ovadiah - Ovadiah 1987: 72 pls. LXXXIV-LXXXV no. 103); flanked by pair of lions at the east end of populated vine scrolls at the synagogue at Ma'on (Nirim; Avi-Yonah 1960a: 2930 fig. 13 pls. VII:4, VIII:1); and within a medallion in the centre of the carpet near the Ark in the synagogue at Jericho (Baramki 1938: 73 pl. XIX). Some of the four species appear in Huldah (Avi-Yonah 1960b: 57-58 fig. 1 pl. XII:3). Finally, depicted in the synagogue at Gerasa are a seven-branched candlestick, Jewish ritual objects, and an inscription, flanked by a pair of lions turning their backs to the symbols (Biebel 1938: 318-323 pl. LXIII: b; Piccirillo 1993a: 290 figs. 546-548).

The candlestick represents the New Year, Day of Atonement, and the Feast of Tabernacles that take place at the beginning of the Jewish New Year, which is the Fall harvest time. The Jewish Midrashim (Biblical commentaries) explain that the Four Species reflect redemption of the penitent from sin, salvation, and the promise of new life after death, just as the ritual brings the long-awaited rain after the dry summer. Together with the depictions of the Holy Ark that are common in synagogues, they have eschatological meaning. 
Conclusions: The Identity of the Complex, the Owner of the House, and His Spiritual and Cultural World

The plan and the identity of the complex are not clear. Zori (1973: 233) identifies the building as a private home, while Hüttenmeister - Reeg (1977: 62-64 no. 8) refer to the possibility that the house was a private home, but according to the wording of the inscription they prefer the interpretation that it was a synagogue. Foerster (1988: 202) recognizes the building as a public building - a hostel for passers-by, as implied by a Greek dedication inscription, since the courtyard adjacent to the synagogue with a water-cistern in the centre was paved with white mosaic, and near the cistern, there are two Greek inscriptions: one mentions the completion of the cistern, and the other: "[Yo]se the great innkeeper and his children made the mosaic of this place. Peace (in Hebrew)". Yose and his children were probably the donors. According to Ruth Ovadiah and Asher Ovadiah (1987: 37), the word 'place' in the inscription does not refer to the synagogue, but to the paved courtyard, which is located more than $10 \mathrm{~m}$ to the south of the synagogue and is separated from it by two walls, and Foerster assumes (1992: 220-221) that the prayer room and Hall 3 served as part of an inn. The identity of the house in my view still remains unresolved, and since the building has not been excavated in its entirety, other than the courtyard, a few small rooms, and two decorated halls, it is likely that this was a wealthy house with a prayer hall.

The name of the owner of the house, Leontis, appears twice in the inscriptions.

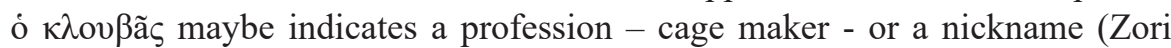
1966: 134; 1973: 234; Roth-Gerson 1987: 165). Lifshitz (1967: no. 77b) also considers that it is the name of a profession derived from the word cage, and that the donor was a craftsman who installed cages and perhaps also engaged in their sale, and he offers another interpretation that the landlord may have made stoves.

Leontis was a common name in the Christian and Jewish communities, for example Leontius Bishop of Madaba in the Chapel of the Theotokos at Mt. Nebo (Saller 1941: 255, 257 pl. 116.3 no. V; Di Segni 1998: 433-434, 465 no. 14), and it was a common name among Jews in the Holy Land and the Diaspora in both Hebrew and Greek, as found in Beth She'arim, Caesarea, Jaffa, and Tiberias (Schwabe - Lifshitz 1967: 21, 33 and there references; Roth-Gerson 1987: 35 note 3, 124 note 27, and there sites and references), and in the synagogue of ElHamme (Sukenik 1935: 129-137). According to the inscription 'Alexandria' in the third panel, and depictions of the Nilotic landscape in Hall 3, Zori and RothGerson suggest identifying the origin of Leontis and his brother Jonathan in the city of Alexandria (Zori 1973: 238; Roth-Gerson 1987: 165).

The mosaic floors of the House of Leontis complex in Nysa Scythopolis (Beth Shean) indicate the use of a common repertoire of both secular and religious motifs and scenes, themes borrowed from Classical mythology together with Jewish symbols.

Kyrios Leontis was an educated man, with knowledge of Jewish literature as well as of classical literature. The use of the three languages was customary in Byzantine Palestine, and also expresses the character of the city of Nysa Scythopolis as a cultural city inhabited by a well-educated, mixed population of Jews, Christians and pagans. The iconography that combines mythological characters with Jewish symbols, and the use of three languages (Hebrew, Aramaic and Greek) indicate the multicultural identity of the landlord, but the two candlesticks, and one accompanied by a ritual object (with part of the Four 
Species) in the mosaic floors in the complex emphasize his Jewish identity.

There is no absolute date for the complex, and on the basis of technical and stylistic analysis, the use of uniformly-sized tesserae and the flat design in Hall 3 may give the mosaic a date from the middle of the fifth century to the early sixth century AD. However, differences in the size and shape of tesserae in the prayer hall, and the semi-voluminous style, reminiscent of the plastic effect portrayals known as the "Justinianic Renaissance" style, allow us to date this mosaic floor to the second half of the sixth century $\mathrm{AD}$, and it is therefore possible that the two halls belong to different complexes ${ }^{10}$ or to an internal development in one complex.

10 In the opinion of Dudi Mevorah, who told me this while discussing the mosaic floors.

\section{Bibliography - Kaynaklar}

Abel 1924

Alföldi-Rosenbaum 1975
M. Abel, “Chronique: découvertes récentes à Beit-Djebrin”, RB 33, 583- 604.

E. Alföldi-Rosenbaum, “A Nilotic Scene on Justinianic Floor Mosaics in Cyrenaican Churches”, CMGR II, 149-152.

Alföldi-Rosenbaum - Ward-Perkins 1980

E. Alföldi-Rosenbaum - J. Ward-Perkins, Justinianic Mosaic Pavements in Cyrenaican Churches (Monografie di Archeologia Libica XIV), Roma.

Avi-Yonah 1933

Avi-Yonah 1934

Avi-Yonah 1936

Avi-Yonah 1960a

Avi-Yonah 1960b

Avi-Yonah 1972

Avi-Yonah 1992

Bagatti 1952

Bahat 1972

Bahat 1981

Balty 1984

Baramki 1938

Baramki - Avi-Yonah 1934

Biebel 1938

Brown 1957

Crowfoot 1938

Dalton 1919

Dauphin 1976

Dauphin 1978

Décor I
M. Avi-Yonah, "Mosaic Pavements in Palestine", QDAP 2, 136-181.

M. Avi-Yonah, "Mosaic Pavements in Palestine", QDAP 3, 49-59.

M. Avi-Yonah, "Mosaic Pavements at el Hammām”, QDAP 5, 11-30.

M. Avi-Yonah, "The Ancient Synagogue of Ma'on (Nirim), the Mosaic Pavement”, BJerus 3, 25-35.

M. Avi-Yonah, "Various Synagogal Remains. Huldah”, BJerus 3, 57-60.

M. Avi-Yonah, “The Haditha Mosaic Pavement”, IEJ 22, 118-122.

M. Avi-Yonah, "Emmaus", E. Stern (ed.), The New Encyclopedia of Archaeological Excavations in the Holy Land, Vol. I, Jerusalem, 37-39 (Hebrew).

B. Bagatti, "Il musaico dell’Orfeo a Gerusalemme", RAC 28, 145-160.

D. Bahat, "The Synagogue at Beth-Shean - Preliminary Report", Qadmoniot 18, 55-58 (Hebrew).

D. Bahat, “A Synagogue at Beth-Shean”, L. Levine (ed.), Ancient Synagogues Reveald, Jerusalem, 82-85.

J. Balty, "Thèmes nilotiques dans la mosaïque tardive du Proche-Orient", Alessandria e il mondo ellenisticoromano, studi in onore di A. Adriani, Roma, 827-834.

D. C. Baramki, “An Early Byzantine Synagogue Near Tell es Sultān, Jericho”, QDAP 6, 73-77.

D. C. Baramki - M. Avi-Yonah, “An Early Christian Church at Khirbat 'Asida”, QDAP 3, 17-19.

F. M. Biebel, “Mosaics”, C. H. Kraeling (ed.), Gerasa, City of the Decapolis, New Haven, 297-351.

B. R. Brown, Ptolemaic Paintings and Mosaics and Alexandrian Style, Cambridge.

J. W. Crowfoot, "The Christian Churches", C. H. Kraeling (ed.), Gerasa, City of the Decapolis, New Haven, $171-262$.

O. M. Dalton, “The Tessellated Pavement of Umm Jerar”, The Burlington Magazine for Connoisseurs 34, 3-10.

C. Dauphin, "A New Method of Studying Early Byzantine Mosaic Pavements (Coding and a Computed Cluster Analysis) with Special Reference to the Levant", Levant 8, 113-149.

C. Dauphin, "Byzantine Pattern Books: A Re-examination of the Problem in the Light of the "Inhabited Scroll", AH I.4, 400-423.

C. Balmelle - M. Blanchard Lemée - J. Christophe - J.-P. Darmon - A.-M. Guimier Sorbets - H. Lavagne - R. Prudhomme - H. Stern, Le Décor géométrique de la mosaïque romaine I, Paris, 1985. 
Derfler 2003

Di Segni 1998

Dothan 1983

Drake 1918

Dunbabin 1978

Dunbabin 1999

Duval 1994

Dvorjetski - Segal 1995

Empereur 2000

Fitzgerald 1939

Foerster 1981

Foerster 1988

Foerster 1992

Foucher 1965

Fradier 1994

Freijeiro 1978

Ganor et al. 2011

Gazit - Lender 1993

Gudovitch 1996

Gutman - Yeivin - Netzer 1981 S. Gutman - Z. Yeivin - E. Netzer, "Excavations in the Synagogue at Horvat Susiya”, L. I. Levine (ed.), Ancient Synagogues Revealed, Jerusalem, 123-128.

Habas 2005

Habas 2012

Habas 2019

Habas 2020

Habas (2021- forthcoming)

Hachlili 1998

Hamarneh 1994

S. Derfler, "The Byzantine Church at Tel Kerioth and Religious Iconoclasm in the $8^{\text {th }}$ century", ARAM 15, 3947.

L. Di Segni, “The Greek Inscriptions”, M. Piccirillo - E. Alliata (eds.), Mount Nebo, New Archaeological Excavations 1967-1997, Jerusalem, 425-467.

M. Dothan, Hammath Tiberias. Early Synagogues and the Hellenistic and Roman Remains, Final Excavation: Report 1, Jerusalem.

F. M. Drake, “A Sixth Century Greek Mosaic at Um Jerar”, PEFQ 50, 122-124.

K. M. D. Dunbabin, The Mosaics of Roman North Africa, Oxford.

K. M. D. Dunbabin, Mosaics of the Greek and Roman World, Cambridge.

N. Duval, "Le rappresentazioni architettoniche”, M. Piccirillo - E. Alliata (eds.), Umm al-Rasas Mayfa'ah. I: Gli Scavi del Complesso di Santo Stefano (SBF, Collectio Maior 28), Jerusalem, 165-230.

E. Dvorjetski - A. Segal, "The Mosaic ,Nile Festival' and its Relation to the Cultural Life in Eretz-Israel in Roman and Byzantine Periods”, Bamah Dramah Quarterly 141-142, 97-109 (Hebrew).

J. Y. Empereur, A Short Guide to The GrÆco-Roman Museum Alexandria, Alexandria.

G. M. Fitzgerald, A Sixth Century Monastery at Beth Shan (Scythopolis), Philadelphia.

G. Foerster, "Synagogue inscriptions and their relation to Liturgical Versions", Cathedra 19, 12-40 (Hebrew).

G. Foerster, "Christian Allegories and Symbols in the Mosaic Designs of Sixth-Century Eretz Israel Synagogues”, D. Jacoby - Y. Tsafrir (eds.), Jews, Samaritans, and Christians in Byzantine Palestine, Jerusalem, 98-206 (Hebrew).

G. Foerster, "Beth-Shean outside the Tell”, E. Stern (ed.), The New Encyclopedia of Archaeological Excavations in the Holy Land, Vol. I, Jerusalem, 209-225 (Hebrew).

L. Foucher, "Les mosaïques nilotiques africaines", La mosaïque gréco-romaine. Colloques internationaux du Centre National de la Recherche Scientifique, Paris, 137-143.

G. Fradier, Mosaïques Romaines de Tunisie, Tunis.

A. B. Freijeiro, Mosaicos Romanos de Merida (Corpus de Mosaicos Romanos de España I), Madrid.

A. Ganor - A. Klein - R. Avner - B. Zissu, “A Byzantine Church and an Underground Hiding-Complex from the Bar-Kokhba Revolt at Horvat Midras in the Judean Shephelah", Judea and Samaria Research Studies 21, 107-124 (Hebrew).

D. Gazit - Y. Lender, “The Church of St. Stephen at Horvat Be'er-Shem'a”, Y. Tsafrir (ed.), Ancient Churches Revealed, Jerusalem, 273-276.

Sh. Gudovitch "A Byzantine Building at the Foot of Horbat Sokho", "Atiqot 28, 17-23 (Hebrew).

L. Habas, The Byzantine Churches of Provincia Arabia: Architectural Structure and their Relationship with the Compositional Scheme and Iconographic Program of Mosaic Pavements, 2 Vols., Unpublished PhD. Dissertation, Hebrew University of Jerusalem, Jerusalem (Hebrew).

L. Habas, "The Mosaic Pavements and Liturgical Furniture of the Church of Bishop John at Khirbet BaraqaGan Yavne", L. D. Chrupcała (ed.), Christ is Here! Studies in Biblical and Christian Archaeology in Memory of Michele Piccirillo, ofm (SBF, Collectio Maior 52), Milano, 131-146.

L. Habas, "The Mosaic Floors and Liturgical Furniture of the Church of Hazor-Ashdod", O. Peleg-Barkat - U. Leibner - J. Ashkenazi - M. Aviam - R. Talgam (eds.), Between Sea and the Desert: On Kings, Nomads, Cities and Monks - Essays in Honor of Joseph Patrich (Land of Galilee 5) Kinneret Academic College and Ostracon, Tzemach, 99*-123* (Hebrew).

L. Habas, "The mosaic floors of the church at Hazor-Ashdod, Israel”, JMR 13, 109-138.

L. Habas, "Mosaic Floors", W. Atrash - G. Mazor - L. Habas (eds.), with Contributions by D.T. Ariel - N. Feig - D. Sandhaus - T. Winter, Nysa-Scythopolis: Ceasarae Gate and Enviorment. Bet She'an Archaeological Project 1986-2002. Bet She'an VI (IAA Reports), Jerusalem.

R. Hachlili. "Iconographic Elements of Nilotic Scenes on Byzantine Mosaic Pavements in Israel”, PEQ 130.2, 106-120.

B. Hamarneh, "I mosaici del complesso di S. Stefano: proposta di lettura", M. Piccirillo - E. Alliata (eds.), 
Hamarneh 1999

Hunt 1994

Hüttenmeister - Reeg 1977

Kitzinger 1965

Kitzinger 1976

Kondoleon 2000

Lafaye 1911

Levi 1947

Lewis 1983

Lifshitz 1967

Lux 1968

Magen 1993

Maguire 1987

Maguire 1999

Makhouly - Avi-Yonah 1934

Meyboom 1995

Michaeli 2013

Naveh 1972

Naveh 1978

Netzer - Weiss 1992a

Netzer - Weiss 1992b

Netzer - Weiss 1994

Netzer - Weiss 1995

Ovadiah 1969

Ovadiah 1997

Ovadiah et al. 1991

Ovadiah - Ovadiah 1987

Piccirillo 1980a

Piccirillo 1980b

Piccirillo 1981

Piccirillo 1983
Umm al-Rasas Mayfa'ah. I: Gli Scavi del Complesso di Santo Stefano (SBF, Collectio Maior 28), Jerusalem, 231-240.

B. Hamarneh, "The River Nile and Egypt in the Mosaics of the Middle East”, M. Piccirillo - E. Alliata (eds.), The Madaba Map Centenary 1897-1997, Travelling Through the Byzantine Umayyad Period, Jerusalem, 185189 .

L-A. Hunt, “The Byzantine Mosaics of Jordan in Context: Remarks on Imagery, Donors and Mosaicists”, PEQ 126, 106-126.

F. Hüttenmeister - G. Reeg, Die antiken Synagogen in Israel, Wiesbaden.

E. Kitzinger, Israeli Mosaics of the Byzantine Period, Milan.

E. Kitzinger, "Mosaic Pavements in the Greek East and the Question of a 'Renaissance' under Justinian", W. E. Kleinbauer (ed.), The Art of Byzantium and the Medieval West, Selected Studies, Mloomington and London, 49-63.

C. Kondoleon, "Floor Mosaic of Beribboned Parrots", C. Kondoleon (ed.), Antioch. The Lost Ancient City, Princeton, N.J., 136-137.

M. G. Lafaye, Inventaire des Mosaïques de la Gaule et de l'Afrique. I: Narbonnaise et Aquitaine, Planches I, Paris.

D. Levi Antioch Mosaic Pavements, 2 Vols., Princeton.

N. Lewis, Life in Egypt under Roman rule, Oxford.

B. Lifshitz, Donateurs et Fondateurs dans les Synagogues Juives, Paris.

U. Lux, "Die Apostel-Kirche in Mādeba", ZDPV 84, 106-129.

Y. Magen, "The Monastery of St. Martyrius at Ma'ale Adummim”, Y. Tsafrir (ed.), Ancient Churches Revealed, Jerusalem, 170-196.

H. Maguire, Earth and Ocean, The Terrestrial World in Early Byzantine Art, London.

H. Maguire, "The Nile and the Rivers of Paradise", M. Piccirillo - E. Alliata (eds.), The Madaba Map Centenary 1897-1997, Travelling Through the Byzantine Umayyad Period, Jerusalem, 179-184.

N. Makhouly - M. Avi-Yonah, “A Sixth-Century Synagogue at 'Isfiyā”, QDAP 3, 118-131.

P. G. P. Meyboom, The Nile Mosaic of Palestrina, Early Evidence of Egyptian Religion in Italy, Leiden.

T. Michaeli, "Allusions to the Nile and Nilotic Landscape in Ancient Art in Israel”, A. Gangloff (ed.), Lieu de mémoire en Orient grec à l'époque impériale, Bern, 109-138.

J. Naveh, Inscriptions Reveal, Jerusalem.

J. Naveh. On Stone and Mosaic. The Aramaic and Hebrew Inscriptions from Ancient Synagogues, Tel Aviv (Hebrew).

E. Netzer - Z. Weiss, "New Mosaic Art from Sepphoris”, BAR 18.6, 36-43.

E. Netzer - Z. Weiss, "Byzantine Mosaics at Sepphoris - New Finds”, IsrMusJ 10, 75-80.

E. Netzer - Z. Weiss, Sepphoris, Jerusalem.

E. Netzer - Z. Weiss, "New Evidence for Late-Roman and Byzantine Sepphoris", J. H. Humphrey (ed.), The Roman and Byzantine Near East: Some Recent Archaeological Research (JRA Suppl. 14), Ann Arbor, MI, $162-$ 176.

A. Ovadiah, "Excavations in the Area of the Ancient Synagogue at Gaza (Preliminary Report)", IEJ 19, 193198.

A. Ovadiah, “Allegorical Images in Greek Laudatory Inscriptions”, LA 47, 441-448.

A. Ovadiah - S. Mochnik - C. Gomez Silva, "A New Look at the Mosaic Floor from Sheikh Zuweid in Ismailiya Museum”, Qadmoniot 95-96, 122-126 (Hebrew).

R. Ovadiah - A. Ovadiah, Hellenistic, Roman and Early Byzantine Mosaic Pavements in Israel, Rome.

M. Piccirillo, "Le antichità di Rihab dei Bene Hasan", LA 30, 317-350.

M. Piccirillo, "The Antiquities of Rihab of the Bene Hasan”, ADAJ 24, 153-156.

M. Piccirillo, “La 'Cattedrale’ di Madaba”, LA 31, 299-322.

M. Piccirillo, "Il complesso monastico di Khirbet Munya nella diocesi di Gerasa della Decapoli", RAC 59, 349-362. 
Piccirillo 1984

Piccirillo 1989

Piccirillo 1992

Piccirillo 1993a

Piccirillo 1993b

Piccirillo 1993c

Piccirillo 1994

Piccirillo - 'Amr 1988

Prausnitz 1967

Qandil 1969

Rahmani 1973

Rahmani 1975

Reinach 1922

Roth-Gerson 1987

Roussin 1981

Saarisalo - Palva 1964

Saller 1941

Saller 1969

Schick - Bliss 1894

Schneider 1937

Schwabe - Lifshitz 1967

Spiro 1992

Sukenik 1932

Sukenik 1935

Sukenik 1949

Sukenik 1951

Talgam 2014

Tammisto 1997

Trendall 1957

Tzaferis 1983

Tsafrir - Hirschfeld 1979

Vincent 1901

Vincent 1919

Vincent 1921

Vincent 1922

Vincent 1961
M. Piccirillo, “Le chiese di Quweismeh-Amman”, LA 34, 329-340.

M. Piccirillo, Chiese e mosaici di Madaba. Documentazione grafica a cura di P. Eugenio Alliata, JerusalemMilan.

M. Piccirillo, “La chiesa dei Leoni a Umm al-Rasas - Kastron Mefaa”, LA 42, 199-225.

M. Piccirillo, The Mosaics of Jordan (ACOR 1), Amman.

M. Piccirillo, "La chiesa dei Sunna' a Madaba”, LA 43, 277-290.

M. Piccirillo, "La chiesa del prete Wa'il a Umm al-Rasas - Kastron Mefaa in Giordania", F. Manns - E. Alliata (eds.), Early Christianity in Context, Monuments and Documents (SBF, Collectio maior 38), Jerusalem, 313 334.

M. Piccirillo, "I mosaici del complesso di Santo Stefano", M. Piccirillo - E. Alliata (eds.), Umm al-Rasas Mayfa'ah. I: Gli Scavi del Complesso di Santo Stefano (SBF, Collectio Maior 28), Jerusalem, 121-164.

M. Piccirillo - A. 'Amr, “A Chapel at Khirbet el-Kursi - Amman”, LA 38, 361-382.

M. W. Prausnitz, Excavations at Shavei Zion, Roma.

H. Qandil, "Excavation of Mosaic Floor in Madaba, Hūsh al-Sārwah”, ADAJ 14, 61-66.

L. Y. Rahmani, “The Erez Mosaic”, EI 11, 263-264 (Hebrew).

L.Y. Rahmani, “The Erez Mosaic Pavement”, IEJ 25, 21-24.

S. Reinach, Répertoire des peintures grecques et romaines, Paris.

L. Roth-Gerson, The Greek Inscriptions from the Synagogues in Eretz-Israel, Jerusalem (Hebrew).

L. A. Roussin, “The Beit Leontis Mosaic: An Eschatological Interpretation”, Journal of Jewish Art 8, 6-18.

A. Saarisalo - H. Palva, “A Byzantine Church at Kafr Kama”, Studia Orientalia 30, 3-15.

S. Saller, The Memorial of Moses on Mount Nebo, Jerusalem.

S. Saller, "The Works of Bishop John of Madaba in the Light of Recent Discoveries", LA 19, 145-167.

B. Schick - F. J. Bliss, "Discovery of a Beautiful Mosaic Pavement with Armenian Inscription, North of Jerusalem”, PEFQSt 26, 257-261.

A. M. Schneider, The Church of the Multiplying of the Loaves and Fishes at Tabgha on the Lake of Gennesaret and its Mosaics, London.

M. Schwabe - B. Lifshitz, Beth She arim. II: The Greek Inscriptions, Jerusalem (Hebrew).

M. Spiro, “Some Byzantine Mosaics from Caesarea”, R. Lindley Vann (ed.), Caesarea Papers 1: Straton's Tower, Herod's Harbour, and Roman and Byzantine Caesarea. Symposium at University of Maryland, JRA Supplementary Series 5, Ann Arbor, 245-260.

E. L. Sukenik, The Ancient Synagogue of Beth Alpha, Jerusalem.

E. L. Sukenik, "The Ancient Synagogue of el-Hammeh”, JPOS 15, 101-180.

E. L. Sukenik, “The Present State of Ancient Synagogue Studies”, BJerus 1, 8-30.

E. L. Sukenik, "More about the Ancient Synagogue of Caesarea", BJerus 2, 28-30.

R. Talgam, Mosaics of Fait, Floors of Pagans, Jews, Samaritans, Christians, and Muslims in the Holy Land, Jerusalem and Pennsylvania.

A. Tammisto, Birds in Mosaics: A Study on the Representation of Birds in Hellenistic and Romano-Campanian Tessellated Mosaics to the Early Augustan Age, Rome.

A. D. Trendall, The Shellal Mosaic, Canberra.

V. Tzaferis, "The Excavations of Kursi - Gergesa", ‘Atiqot 16.

Y. Tsafrir - Y. Hirschfeld, "The Church and Mosaics at Horvat Berachot, Israel”, DOP 33, 293-323.

H. Vincent, “Chronique: Une mosaïque byzantine à Jérusalem”, RB 10, 436-448.

H. Vincent, "Le sanctuaire juif d'Aïn-Douq", RB 28, 532-563.

H. Vincent, “Chronique: Le sanctuaire Juif d"Aïn-Douq”, RB 30, 442-443.

H. Vincent, “Chronique: une villa Gréco-Romaine à Beit Djebrin”, RB 31, 259-281.

H. Vincent, "Un sanctuaire dans la région de Jéricho, la synagogue de Na`aran”, RB 68, 163-173. 
Weiss 2005

Weiss - Netzer 1996

Weiss - Talgam 2002

Whitehouse 1979

Zissu et al. 2016

Zori 1966

Zori 1967

Zori 1973

Z'ubi et al. 1994
Z. Weiss, The Sepphoris Synagogue: Deciphering an Ancient Message through Its Archaeological and SocioHistorical Contexts, Jerusalem.

Z. Weiss - E. Netzer, "The Mosaics of the Nile Festival Building”, R. M. Nagy - C. L. Meyers - E. M. Meyers - Z. Weiss (eds.), Sepphoris in Galilee: Crosscurrents of Culture, North Carolina, 127-131.

Z. Weiss - R. Talgam "The Nile Festival Building and its mosaics: mythological representations in early Byzantine Sepphoris", J. H. Humphrey (ed.), The Roman and Byzantine Near East 3, Portsmouth, Rhode Island, 55-90.

H. Whitehouse, A Catalogue of Nilotic Landscapes in Roman Art, Unpublished PhD. Dissertation, Oxford University, Oxford.

B. Zissu - A. Kloner - A. Ganor - R. Avner - A. Klein, "Horvat Midras (Khirbet Durusiya): An Ancient Settlement and its Artificial Cavities in the Judean Foothills, Israel", Opera Ipogea 2, 11-28.

N. Zori, “The House of Kyrios Leontis at Beth-Shean”, IEJ 16, 123-134.

N. Zori, “The Ancient Synagogue at Beth-Shean”, EI VIII, 149-167 (Hebrew).

N. Zori, "The house of Kyrios Leontis at Beth-Shean”, EI 11, 229-247 (Hebrew).

I. Z'ubi - P.-L. Gatier - M. Piccirillo - J. Seigne "Note sur une mosaïque à scène bachique dans un palais d'époque byzantine à Jérash", LA 44, 539-546. 
